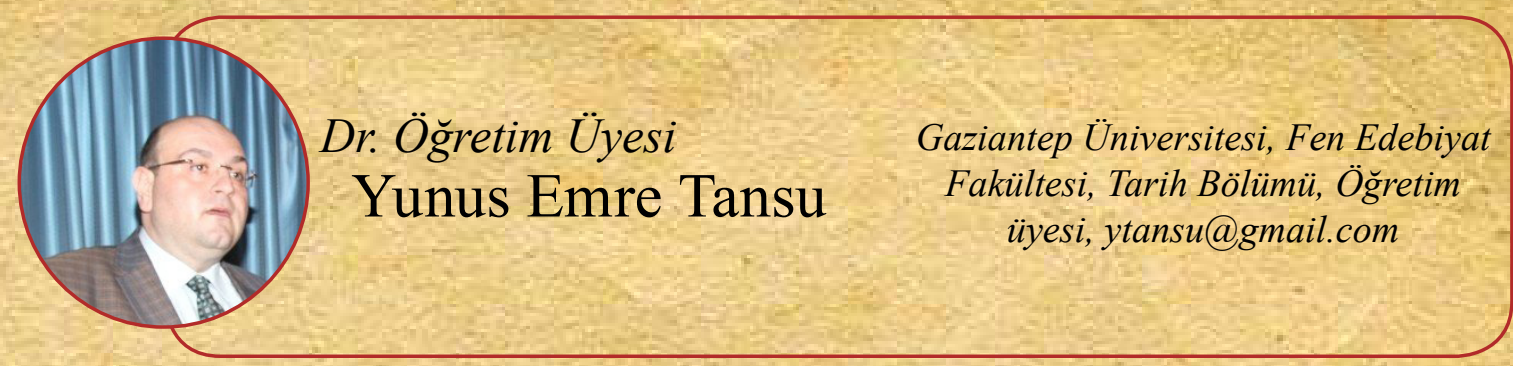

Eser Geçmişi / Article Past: 10 Nis 2018 / 17 Nis 2018

Araştırma Makalesi

DOI: $10.21551 / \mathrm{jhf} .414316$

Research Paper

Orjinal Makale / Orginal Paper

\title{
Osmanlı İmparatorluğu’nda Batıcı Düşünce Çerçevesinde Dr. Abdullah Cevdet Ve İctihad Dergisi
}

\section{During Ottoman Empire, Dr. Abdullah Cevdet and Journal of İctihad as in the Frame of the West Thought}

\section{ÖZET}

Osmanlı Devleti, XVIII. yüzyıldan itibaren Batılılaşma çabaları içine girmiştir. Bu çabalar, önce askerî alanda veXIX. Yüzyılda ise toplumsal ve İdarîalanlarda gerçekleştirilmiş devleti yöneten geleneksel elit tarafından hoşnutsuzlukla, ulemâ tarafından ise şüphe ile karşılanmıştır. Diğer yandan bu gerilim, toplumda büyük bir dinamizme yol açmıştır. Bir yanda aşırı Batıcılardan, öte yanda Batıdan hiç hoşlanmayan ve ancak devletin bekası için Batılılaşmak zorunda olduğunu hissedenler ile Batılı olan her şeyden uzak durmayı yaşam tarzı olarak benimseyen aydınlardan ve bu konulara tamamen ilgisiz bir halktan oluşan Osmanlı toplumu, Batıcılığı kapsamlı bir problematik olarak görmüştür.

Dr. Abdullah Cevdet'in yayımladığ 1 îctihad Dergisi, Batıcılığ 1 bir hayat tarzı olarak görmekte ve en aşırı düzeyde Batıcılığı Batı ile "aynîleşmeyi" savunmaktadır. Dergi, 28 yıllık yayın hayatı boyunca çağdaşları arasında en kararlı, istikrarlı ve ısrarlı bir şekilde Batıcılığı sürekli savunmuştur. Her olayı, her konuyu ve her meseleyi, Batıcı bir tarzda çözmeyi, anlamayı ve aşmayı prensip edinmiştir. Bu anlayış, çağdaşı aydınlar tarafından çok şiddetle eleştirilmiştir.

Her zaman Batıcılığ savunmakla beraber, 1904-1908 yıllan arasinda Sultan Abdülhamid'e karşı en şiddetli muhalefeti de yürütmüştür. îctihad, Meşrutiyet'in ilânından büyük bir memnuniyet duymakla beraber, Meşrutiyet döneminde, Batıcılık alanında beklediklerinin beklediği hızla gerçekleşmemesinden dolayı 1913 - 1918 yılları arasında İttihad ve Terakki Cemiyeti iktidarına karşı da muhalefet yürütmüştür. Bu arada İslâmcı 
basın tarafından dinsizlikle suçlanmıştır. Ayrıca İttihatçılara karşı, gerektiğinde İslâmcılar ile de işbirliği yapmıştır.

Anahtar kelime: Osmanlı devleti, Dr. Abdullah Cevdet, İctihad dergisi

\section{ABSTRACT}

The Ottoman Empire started to make westernization efforts in the XVIIIth century. These efforts have been formerly realized in military field and in the XIXth century both in social and administrative fields. These efforts were taken with dissatisfaction by society and with suspicion by the clergy. This tension caused a great dynamism in the society. On one side extreme Westernizationers on the other side those who hate the West and for this reason want to become westernized and on the another side intellectuals who avoid anything coming fom the West by assuming it as a life style and also Ottoman society composed of completely disinterested public accepted the westernization as a social, administrative and important problem.

Ictihad Dergisi (Journal) that was published by Dr. Abdullah Cevdet, accepted westernization as a life style and extremely defended westernization "being the same as West". Through the 28 years of publish of the Journal of İctihad, it continiously defended westernization in the most fixed, stable and insistent way. It had as a principle to understand and to analyze every event, every subject and every question in a western way. This understanding was criticised violently by its contemporary intellectuals.

Concurrently always defending westernization, it opposed in a most violent way against Sultan Abdülhamid in the course of years 1904-1908. İctihad not only having great satisfaction by the declaration of Meşrutiyet but also o pposed the İttihat Terakki Assembly government in the course of years 1913-18 since there has not been a rapid development in the field of Westernization in Meşrutiyet era as they expected it to be. Meanwhile it was accused of being irreligiousness by Islamic Press. In addition, against the Ittihadists made a cooperation with Islamists if needed.

Keyword: The Ottoman state, Dr. Abdullah Cevdet, İctihad magazine

*Bu makale Dr. Yunus Emre TANSÜ, Doktora Tezinden bir bölümü hazırlanmıştır.

\section{GíRIŞ}

Günümüzde ilim adamları, çağdaşlığın gündelik hayatın bir gereği olup olmadığı konusunu tartışmayı çoktan bırakmışlardır. Zira çağdaşlık, Bilgi Çağı'nda hayatın bir gerekliliği haline gelmiştir. Artık nasıl çağdaşlaşma gerçekleştirilebilir sorusuna cevap aranmamaktadır. Çünkü çağdaşlaşmanın ancak gelişmiş ve müreffeh bir toplum yaşantısı ile olabileceği konusunda kimsenin şüphesi yoktur. Günümüzde Türkiye, Bilgi üreten ve ürettiği bilgiyi kiralayan bir ülke mi, yoksa bilgi kiralamaya devam eden bir ülke mi olacak sorusu tartışılmaktadır. Dikkat edilirse "bilgi kiralama" terimi kullanılmıştır. Çünkü artık 
sanayi toplumu çağının, teknoloji satın alma dönemi geçmiştir. Halihazırda dünyada iki tür toplum vardır: bilgi üretenler ve bilgi kiralayanlar. Kiralanan her bilgi, gelişmekte olan topluma ulaştıktan birkaç ay sonra eskimekte ve yenilenmeye ihtiyaç duymaktadır. Bilgi kiralama, pahalı ve zor iştir. Çok büyük bedeller ödenerek transfer edilen bilgi, çok kısa ömürlü kullanılmaktadır. Bu durum, özellikle tam gelişememiş olan toplamlarda devlete ağır bir yük getirmektedir.

Günümüzde bilgi üreten toplumlar, sanayi toplumu çağındaki kapitalist ülkelerdir. Kapitalizme geç ulaşan doğulu bir toplum olan Japonları da unutmamak gerekir. Bilgi üreten geçen yüzyılın kapitalist ülkeleri ile gelişen, gelişmeye çalışan veya geri kalmış ülkeler arasında sürekli bir etkileşim vardır. Zira ikincileri birincilerine yetişmek, onlar gibi yaşamak için büyük gayret sarf etmektedirler.

Halbuki sanayi öncesi dönemde iki değişik kültür olan Doğu ile Batı arasında ticarî ilişkiler ile savaşlar dışında toplumsal boyutta münasebet mevcut değildir. İçine kapanık olan Çin ile sömürgeleştirilmiş Asya, Afrika ve Amerika'ya göz ardı edecek olursak, Doğuyu Müslüman Osmanlı Devleti, Batıyı ise sömürgeci Batılı Hıristiyan Devletler temsil etmektedirler.

Osmanlı Devleti, kurulduğu günden beri Batıyı sadece savaş yapılacak veya ticarî ilişkide bulunulacak bir yer olarak görme alışkanlığındadır. Fethettiği yerler dışında Batıyı hiç merak etmemiştir. Halbuki yüzyıllardır Batılı seyyahlar Doğuyu tanımak için karış karış gezmekte ve bu izlenimlerini yayınlamaktadırlar.

Türklerde Batılılaşma ne zaman başlamıştır sorusuna cevap bulmak zordur. Küçümsenen ve merak edilmeyen Batının önem kazanması için uzun bir sürenin geçmesi gerekmektedir. Batıda meydana gelen gelişmelerden Rönesans, Reform, Coğrafî Keşifler ve Aydınlanma, sadece Osmanlı Devleti'nin siyasetini ve ticaretini etkilediği ölçüde etkilenmiştir. Sözgelişi Portekizlilerin Hindistan'a ulaşması ve buradan ticareti engellemesi, Coğrafî Keşiflere dikkati çekmiştir.

Osmanlı Devleti'nin bu tutumunu, günümüz koşullarında yaşadıkları için ilim anlayışından uzak bazı çevreler gibi eleştirmek, o çağın koşullarını bilmemekten ve dönemleri şartları ile birlikte değerlendirememekten kaynaklanan bir meseledir. Osmanlı Devleti, Müslüman bir devlet olarak Roma İmparatorluğu'nun ardından, bilinen dünyanın önemli bir kısmına sahip olmuş bir devlettir. Batıklar sürekli yenilmekte olan ve Hiristiyan oldukları için "Hidayet"e erememiş ve yaşantı olarak da İslâmî bir hayat sürmediklerinden dolayı aşağı görülen insanlardır. Dolayısıyla Osmanlıların Batılılaşma için bir zorunlulukları yoktur. Hangi toplum, hayat tarzı kendisinden aşağı olan bir toplumu örnek alır? Ancak bu, Doğu ile Batı arasında etkileşim olmadığı anlamına da gelmemektedir. Her iki toplum arasında kadim zamanlardan beri yoğun bir etkileşim bulunmaktadır. Doğu ve Batıda üretilen mallar ve bu malların kültürleri, kullandığı toplumlarda bir etki teşkil etmektedirler. Ancak bu durum, söz konusu malların kullanımı ile sınırlıdır.

Osmanlı Devleti, Batılılaşmaya ne zaman başladı sorusuna cevap ararken, kastedilen

1 Bu konuda bkz. Tunaya 1989 
Batıc1lığın kurumsal bir halde kabulüdür. Bundan önce XVII. yüzyılda Osmanlılar, Batılılar karşısında ağır yenilgiler aldıklarında Osmanlı uleması bu durumu bir bozulmanın sonucu olarak görmüşlerdir. Koçi Bey ve Katip Çelebi gibi figürler, "Altın Çağ" olarak karakterize edilen büyük fetihler çağının, yani Fatih Sultan Mehmet, Yavuz Sultan Selim ve Kanuni Sultan Süleyman dönemlerine geri dönüşü arzulamışlardı. Onlara göre, devlet işleyişindeki aksaklıklar giderilir ve bozukluklar onarılırsa, "Altı̣ı Çağ" geri dönecektir. Bu eskiye özlem duygusu, XVII. yüzyıla damgasını vurmuştur. Fakat beklenilen sonucu vermemiştir. Zira bozukluklar artarak devam ettiği gibi, yenilikler de daha da yoğunlaşarak devam etmiștir. $\mathrm{Bu}$ dönemde Osmanlı devlet adamları Batının hiç değilse askerî alanda Osmanlılardan daha ileri gittiği gerçeğini kabul etmek zorunda kalmışlardır. Hiç kuşkusuz kendini Hıristiyanlardan üstün gören bir anlayışa sahip olan Müslüman bir devletin yöneticileri için, söz konusu durumun kabulü çok güç olmuştur. Zira böylece İslâm'ın üstünlügünün de zarar gördüğü şeklindeki kanaati yaygınlaşmıștır. Bu sebeple Batı ile "aynileşme" ve Batıyı yenme amacıyla, Batıdaki askerî alandaki yeniliklerin transferi amaçlanmıştır.

$\mathrm{Bu}$ dönemde Osmanlı ordusunun ana unsuru olan Yeniçerilere dokunulmadığından, ordunun diğer bölümlerinde Avrupa'dan getirilen uzmanların gözetiminde bir değişim başlamışsa da, ordunun esas unsurunu etkileyecek boyutta olmadığından yetersiz kalmıștır. Fakat ordudaki yenileşme ve değişim çabaları, Batının üstünlüğüne karşı etkili olmadığ gibi, askerî alanda başlayan etkileşim, Batının başarısının sadece askerî alanda olmadığını da ortaya koymuştur. Özellikle Lale Devri'nde başlayan ve daha sonra da sıklaşan ilişkiler, Osmanlıların başka alanda Batıdan yenilik transferine ihtiyaç olduğunu ortaya koymuştur. ${ }^{2}$

XIX. yüzyılda ise, Sultan III. Selim dönemi ile başlayan bir süreçte devletin ve toplumun her alanında Batılılaşma başlamıştır. Bu Batılılaşma çabaları, Batıda olduğu gibi tabandan tâvana doğru olmamıştır. Tam tersine tepeden tabana doğru olduğundan birçok tartışma konusu ortaya çıkmıştır. Toplumun, temel ihtiyaçlarının temini dışında bir beklentisi yoktur. Batılılaşma, daha ziyade yönetici elit aydın tabakanın, devletin bekasını sağlamak için istediği bir konudur. Zira son dönem Osmanlı yönetici elitinin en büyük meselesi, devleti yıkılmadan korumak, toprak kaybını en aza indirmek, sosyal çöküntüyü engellemek ve devletin bekasını sağlamak olmuştur.

Sultan II. Mahmut, Tanzimat ve Meşrutiyet dönemlerinin esas amaçlan bunlar olarak özetlenebilir. Bu üç dönem, kendinden önceki yapılan Batılılaşma çabalarının devletin bekası açısından beklenen neticeleri vermemesinin sonucu olarak oluşmuştur. Sultan II. Mahmut döneminde yapılan yeniliklerin sonuç vermemesi Tanzimat'1 doğurmuştur ${ }^{3}$, Tanzimat' in bekleneni vermemesi ise Meşrutiyeti getirmiştir. Hatta Tanzimatçıları yeterince hızlı yenilik yapmamakla, başarılı olmamakla suçlayan genç Osmanlı aydınları, "Yeni Osmanlılar" (Jön Türkler) adı altında teşkilatlanmış ve mevcut Tanzimat idaresine karşı mücadeleye girişmişlerdir. Bunların amacı anayasal parlamenter bir demokrasidir. Yeni Osmanlılar, başarıya ulaşmış ve Meşrutiyet ilan edilmiştir. ${ }^{4}$

2 Bu konuda ayrıntılı bilgi için bkz. Öz 1997; Osmanlı toplumundaki çözülme ve bunun engellenmesi için gelenekçi yorumları açiklamaktadır. Ayrıca bu sorunların ortaya konulması için Berkes 1965; Berkes 1975; Berkes 1978. Lewis 1984.

3 Tanzimat hakkında bkz. 150.Yılında Tanzimat 1992; Ali Reşad 1328, 150.YılındaTanzimat 1990.

4 Yeni Osmanlılar lık.bkz. Mardin 2001: 42-53; Koçak 2001: 72-87 
Ancak anayasal meşrutî idare de uzun sürmemiştir. Sultan II. Abdülhamid, meşrutî idareyi askıya almış ve bir ara dönem başlatmıştır. Bu ara dönemde, Hamidî Rejime muhalefet amaciyla "Ittthad ve Terakki Cemiyeti" kurulmuştur. ${ }^{5}$ Bu cemiyet XIX. yüzyılda Avrupa'yı etkileyen ve "Bilim Dini" olarak da nitelendirilen Pozitivizmdin "birleşme" ve "ilerleme" prensipleri başta olmak üzere ilkelerinden etkilenmiştir. Bu cemiyet, bir yandan Sultan II. Abdülhamid yönetimine yön verip meşrutî bir monarşi teşkiline çalışmakta ve bir yandan da Batıcılığı savunmaktadır. Bu amaçla yapılan muhalefet, İttihad ve Terakki Cemiyeti üyelerinin cezalandırılmasına yol açmış ve bazıları sürgün edilirken bazıları ise yurt dışına kaçıp muhalefeti oradan sürdürmüşlerdir. Bu muhalefet esnasında, en çok gazete ve dergi çıkarmak yoluyla halkı bilinçlendirmeyi ve Hamidî Rejimi yıkmayı istemişlerdir. $\mathrm{Bu}$ muhalefetin en önemli unsurlarından biri de, İttihad ve Terakki Cemiyetinin beş kurucusundan biri olan Dr. Abdullah Cevdet'in 1904 yılında Cenevre'de kurduğu "İctihad Dergisi" dir.

İttihad ve Terakki Cemiyeti içinde, Hamidî Rejim'e muhalif değişik görüşte birç̧ok kişi toplanmıştır. Bunlar arasında Dr. Abdullah Cevdet gibi, Batıcılığı Türkiye için tek kurtuluş çaresi olarak görenler olduğu gibi, 1 lımlı bir batıcılığı savunanlar da vardır. Beşir Fuad ${ }^{6}$, Dr. Abdullah Cevdet, Baha Tevfik, Ahmed Rıza, Ahmed Şuayb, Batıcılık konusunda Batı ile aynılaşmayı, Doğu yerine Batı tipi sosyal hayatı amaçlamaktadırlar. Bunlara Osmanlı Pozitivistleri veya Osmanlı Materyalistleri adı da verilmektedir.

Osmanlı materyalizminin kurucusu, Beşir Fuad'dır. ${ }^{7}$ Beşir Fuad, insan gerçeği üzerinde incelemelerde bulunmuştur. Tanzimat'ın "insan" tanımına karşı çıkması, insanın nesnel gerçekliğini tespit etmesi ve insandan kaynaklanan meselelerde varoluş problemini incelemesi, Osmanlı materyalizminin ilk evresini oluşturmuştur. Beşir Fuad' $1^{8}$ Ahmed Şuayb takip etmiştir. Ahmed Şuayb, sanatın bilimin gelişimini açıklayamadığı noktasında bilimsel determinizme açık bir eleştiride bulunmaktadır. Beşir Fuad ve Ahmed Şuayb, Osmanlı Materyalizminin ilk temsilcileri olarak, Dr. Abdullah Cevdet'ten biyolojik materyalizme yönelme konusunda ayrılmaktadır. ${ }^{9}$ Dr. Abdullah Cevdet, biyolojik materyalizme uzanan kesin Batıcılığı noktasında, Doğu medeniyetinden de istifade edilmesini savunurken, Baha Tevfik ${ }^{10}$ ise Doğuya ve dolayısıyla İslâm'a ait olan her şeye karşı bir anlayışı savunmaktadır. ${ }^{11}$ Baha Tevfik, bireysel ahlak bozukluğunun Osmanlı ilerlemesinin engeli olduğunu ifade etmektedir.

Ahmed Rıza ${ }^{12}$, Osmanlı pozitivizminin ilk temsilcisi olarak, siyasî ve etik bir Pozitivizm'i savunmaktadır. Onun için önemli olan, "düzen" içinde, "îlerleme" dir. Ahmed Rıza, Auguste Comte'un Pozitivizm'inden en çok etkilenen kişidir. Ahmed Rıza, "birey"i, "bireyin içinde olduğu düzen"i ve "adaleti ve düzeni sağlayıcı bir unsur olarak ahlâk"1

5 İttihad ve Terakki Cemiyeti'nin kuruluşu içi bkz.Kuran 1948

6 Beşir Fuad için bkz. Okay 1969.

7 Ayrıntılı bilgi için bkz. İşıı 1985b: 365-367

8 Ayrıntılı bilgi için bkz. Işın 1985b: 367

9 Bu konularda bkz. Bolay 1967

10 Ayrıntılı bilgi için bkz. Işın 1985b: 368-370; Bağc1 1994.

11 Bkz. Tunaya 1991.

12 Ayrıntılı bilgi için bkz. İşın 1985a: 356-359; Özden 2001: 120-123 
tanımlamak suretiyle Batıcılığı bir soyut anlayış olmaktan kurtarmış ve halk için somut bir olgu haline getirmiştir.

İctihad, 1904-1908 yılları arasında Hamidî Rejimi önce Cenevre ve daha sonra da Kahire'de sürdürürken, daha sonraki yıllardaki Batılılaşma çabalarına ve Cumhuriyet inkılâplarına ilham kaynağı olacak laiklik, harf meselesi ve kadın hakları gibi konuları ilk defa dile getirmektedir.

İ́ctihad, Meşrutiyet'in ilânından büyük sevinç duymuş ve idare merkezini İstanbul'a taşımış ise de, kurucusu Dr. Abdullah Cevdet, îttihad ve Terakki Cemiyeti'nin kurucularından olmasına rağmen, İstanbul'da beklediği ilgiyi görememiştir. Çünkü Avrupa'da padişah ile anlaşmış ve davaya ihanet etmiş, geçimsiz kişiliği arkadaşları tarafından dişlanmış ve İttihad ve Terakki Cemiyeti içindeki yeniden oluşumda muhalif grup olan Prens Sabahaddin'in çevresinde toplanan Adem-i Merkeziyetçiler arasında yer almıştır. Bu sebeple Dr. Abdullah Cevdet ve İctihad İstanbul'daki İctihad çevrelerinde şüpheyle karşılanmış ve hatta bu dönemde Kürtçülük yapmakla suçlanmıştır. Daha sonra İctihad, İttihad ve Terakki Cemiyeti'nin muhalifleri arasında yer almış, 1913-1918 yılları arasında mevcut İttihad ve Terakki iktidarının bütün baskılarına rağmen, bu muhalefeti zaman zaman da İslamcılar ile işbirliği yapmak suretiyle sürdürmüştür. Aslında ileri sürdüğ̈̈ fikirlerden ötürü, İslâmcilar ile çok şiddetli bir mücadeleye başlamıştır. İslâmcılar, bu mücadelede daha üstün bir durumda gözükmektedirler. İslâmcılar, İctihad'ı dinsizlik propagandaları yapmakla ve Dr. Abdullah Cevdet başta olmak üzere yazarlarını da dinsizlikle suçlamaktadırlar. Zaman içinde İctihad yazarlarından Celâl Nuri İleri ${ }^{13}$, Batıdan sadece teknoloji transferi yoluyla Batılılaşmayı savunduğu için İctihad ile yolları ayrılmıştır.

İctihad, döneminin serbest bir platformu olarak Batıcılığı savunmak kaydıyla her türlü fikre sayfalarını açmıştır. Bu yazar kadrosu, çok renkli ve zengindir. Ancak en istikrarlı yazar, kurucu Dr. Abdullah Cevdet'tir. İctihad, Anadolu'daki Millî Mücadele'ye ilgisiz kalmıștır. Zira Dr. Abdullah Cevdet, Hürriyet ve İtilâf Fırkası'nın bir destekçisi, Damat Ferit hükümetlerinde iki kez Sıhhiye Umum Müdürü ve İngiliz Muhipleri Cemiyeti'nin beyannâmesini hazırlayanlar arasında bulunduğu için Anadolu'daki Millî Mücadele kazanıldıktan sonra, İctihad'ın ön plana çıkmasını da engellemiştir. Sultan II. Abdülhamid döneminde Batıcılığa yön veren İctihad, Cumhuriyet döneminde fiilî etkinliğini yitirmiştir.

İctihad, Cumhuriyet idaresi döneminde yıllardır savunduğu ilkelerin hayata geçirilmesinde, etkin bir rol oynayamamıştır. Cumhuriyet idaresi, bir zamanlar İctihad'ın savunduğu prensipleri, inkılâplar halinde hayata geçirirken, İctihad ve kurucusu Dr. Abdullah Cevdet, bu olayların içinde destekçilikten öte bir görev ifa edememiştir. Cumhuriyet döneminde İctihad' da çıkan yazılar, Cumhuriyetten önceki dönemde yayımlanan yazılardan karakteristik olarak farklıdır.

İctihad Dergisi, 1932 yilında Dr. Abdullah Cevdet'in vefatına kadar yayımlanmaya devam etmiş ve bu vefattan sonra çıkan 358. sayı ile sona ermiştir. 


\section{A- DR. ABDULLAH CEVDET ${ }^{14}$}

Türk Düşünce Hayatında istikrarlı bir biçimde Batıcılığı savunan ender fikir àdamlarından olan Dr. Abdullah Cevdet, 9 Eylül 1869 tarihinde Arapkir'de dünyaya gelmiştir. Dr. Abdullah Cevdet, Arapkir eşrafından Üstad Ömeroğulları ailesine mensuptu ve babası ordudan emekli olmuş olan Hocazâde Elhac Ömer Vasfı Efendi idi. İlköğrenimini Hozat ve Arapkir'de tamamladıktan sonra, ailesi ile birlikte Mamüratül'aziz Askerî Rüşdiyesi'ni bitirmiş ve İstanbul'a gelerek Kuleli Askerî Tibbiye İdadisi'nde okumuştur. Daha sonra İstanbul'a Askerî Tibbiyesi'ne kaydolmuştur (1888).

Burada okurken daha sonra İttihad ve Terakki Cemiyeti'nin önde gelen isimlerinden olan İbrahim Temo, Hüseyinzâde Ali, Doktor Nazım ve Bahaeddin Şakir ile ünlü filozof Rıza Tevfik ile sınıf veya okul arkadaşlığı yapmıștır. Kürt kökenli bir aileden gelen, ancak etnik ayırımcı bir Kürtçülüğe hayatı boyunca karşı olan Dr. Abdullah Cevdet, bu yıllarda namazında niyazında oldukça dindar birisi olarak tanınmaktadır. İbrahim Temo'nun, teşvikiyle Felix İsnard'ın "Spritualisme et Materialisme" adlı kitabını okumasıyla dine karşı ilk şüpheleri uyanmıştır.

1889 yilında istibdat yönetimine tepki duyan beş arkadaş, Fransız Devrimi'nin 100. yıldönümünde 3 Haziran 1889 gecesi okulun arkasındaki bir kömürlükte hiç ışık olmayan bir ortamda İttihad-1 Osmanî Cemiyeti'ni kurmuşlardır. Daha sonra İttihad ve Terakki Cemiyeti adını alacak bu demeğin ilk beş kurucusu, Dr. Abdullah Cevdet, İbrahim Temo, Mehmed Reşid Şahingiray, İshak Sükûti ve Hikmet Emin'dir.

Dr. Abdullah Cevdet, okul yıllarında dindar, sert mizaçlı, kavgacı ve geçimsiz bir imaj çizmiştir. Önce Abdullah adını kullanırken, öğrencilik yıllarında yazdığı yazılarda "Ömer Cevdet" takma adını kullanmasından dolayı, imzasını Abdullah Cevdet olarak atmaya başlamıştır.

Dr. Abdullah Cevdet, öğrenciliği esnasında yaşayan en büyük şairlerden biri olarak nitelendirdiği Abdülhâk Hamid'i Çamlıca'da köşkünde ziyaret etmiş ve ondan çok etkilenmiştir. Abdülhâk Hamid'in teşviki ile şiirlerini toparlayıp kitaplar halinde yayımlamıştır. İlk şiir kitabı, "Hiç"tir (1890). Onu "Tuluat" (1891), “Türbe-yi Masumiyet" (1890) izlemiştir.

Dr. Abdullah Cevdet, Louis Buchner'in "Matiere et Force" adlı eserini okuduktan sonra, düşünce yapısında büyük değişiklikler meydana gelmiştir. Bu eserin bir bölümünü "Fizyolociya-yı Tefekkür" adıyla Türkçe'ye tercüme etmiştir. Dr. Abdullah Cevdet, bu dönemde Kari Vogt, Emest Haeckel, Spencer gibi ünlü Batılı fikir adamları ile Namık Kemal,

14 Dr. Abdullah Cevdet'in hayatı için şu kaynaklardan yararlanılmıştır: Ülken 1994: 246-256; Hanioğlu 1988: 90-93; Mardin 1983: 163-183; Abdullah Cevdet... 1932: 5875-5876; Kemal Cenap 1932: 5876-5879; Ebubekir Hazım 1932: 5879-5881; Abdiilhâk Hamid 1932: 5883;

Lütfi Fikri 1932: 5883-5887; M.Fuad 1932: 5887; Nuri Fehmi 1932: 5888-5889; İsmail Hakk1 1932: 5889-5890; Fuat Hulusi 1932: 5890; Operatör Kazım...1932:5891-5892; Celal Nuri 1932: 5892-5893; M. Ferit 1932: 5894; Filorinalı Nazım 1932: 5894; Hüseyinzâde Ali 1932: 5895-5897; Muharrem Zeki 1932: 5897; Abdullah Cevdet Merhumun... 1932: 5898-5899; Biirhan Şakir 1932 5900-5901. 
Recaizâde Mahmud Ekrem, Abdülhâk Hamid ve Halit Ziya'nın etkisi altında kalmıştır. İlk düzyazı edebî eseri olan "Ramazan Bahçeleri”ni 1891'de kaleme almıştır. Edebî anlayışını Menemenlizâde Tahir'in etkilediği söylenilmektedir.

Dr. Abdullah Cevdet, felsefe ve sağlik konularında "Dimağ" (1890), "Fizyolociya ve Hıfz-1 Sıhhat-i Dimağ" ve "Melekât-1 Akliyye" (1894) adlı eserlerini yayımlamıştır. 1894 'te "Masumiyet" adlı şiir kitabını neşretmiştir.

Dr. Abdullah Cevdet, 1894 'te Askerî Tıbbiye'den olaylı bir şekilde mezun olmuştur. Okuldaki siyasî faaliyetleri sebebiyle soruşturulmuş ve gözaltına alınmıştır. Ancak yargılanmadan serbest bırakılmıştır. Ancak yargılanmadan serbest bırakılmıştır. Mezun olduktan sonra Haydarpaşa Hastanesi'nde, Dr. Diran Acemyan'ın asistanı olarak göz doktoru yardımcisı olmuştu.

Dr. Abdullah Cevdet bu dönemde Andre Chenier, Musset, Lamartine, Françoise Coppee, Ömer Hayyam, Shakespeare, Byron, Daubes, Letoumeau, Le Moynac gibi düşünür ve yazarlardan etkilenmiştir.

Dr. Abdullah Cevdet, geçici görevle 1894 yılında kolera mücadelesi için Diyarbakır'a yollanmıştır. Burada İttihad-1 Osmanî Cemiyeti'nin teşkilâtlanması için çalışmıştır. Bu arada Ziya Gökalp'in bulunduğu bazı kişileri teşkilâta dahil etmiştir. 1894'te "Kolera" adlı eserini yayımladı. Aynı yıl Elazığ'da Büchner'in "Natur und Geist" adlı eserini "Goril" adıyla tercüme ederek neşretmiştir.

İstanbul'a dönünce Ermeni olayları sebebiyle kızgınlaşan hava içinde bazı broşürler yayımlaması üzêrine, İstanbul'dan uzaklaştırılmak için Adapazarı Redif Taburu tabipliğine atanmıştır. Ancak bu göreve başlamadan, yayımladığı broşürlerden biri olan Itttihad-1 Osmanî ile ilgili bir beyanname yüzünden "erbab-1 fesad"dan kabul olunarak 53 arkadaşıyla birlikte tutuklanmıştır (1895). Ardından Bakanlar Kurulu kararıyla Trablusgarb’a sürülmüştür (1896). Burada bir süre kale zindanında hapsedildikten sonra, Vali Vekili Recep Paşa'nın yaveri Şevket Bey'in gayretleri ile kalede serbest dolaşımına izin verilmiş ve İttihad ve Terakki adını alan İttihad-ı Osmanî 7 numaralı Trablusgarb Şubesi'ne kaydolmuştur. Bu arada Trablusgarb Askerî Hastanesi göz hekimliğine tayin edilmiștir.

Bu görevi esnasında Avrupa'da bulunan Ahmed Riza ve Mizancı Murad ile gizlice haberleşmiş, bunların yayımladığı Mizan, Meşveret ve Mechveret Supplement Français dergilerine "Bir Kürd" adıyla veya imzasız yazılar yazmıştır.

Bu sırada aynı hastanede çalışan Süleyman Kadara adlı bir hekim tarafından Saray’a gizli faaliyetleri jurnallenmiştir. Bunu haber alan ve Trablusgarb'tan Fizan'a sürülmek üzere olan Dr. Abdullah Cevdet, bir yelkenli ile Tunus'a firar etmiş ve oradan da Fransa'ya geçerek Paris'e gitmiştir (1897).

Avrupa' daki Jön Türkler, bu sırada yol ayrımı içindeydiler. Mizancı Murad'ın Ahmed Celâleddin Paşa ile anlaşarak, İstanbul'a dönmesi üzerine Avrupa'daki İttihad ve Terakki hareketi zor duruma düşmüş ve kararsızlık içinde kalmıştır. Gerçekten de Mizancı Murad'ın İstanbul'a dönmesi, hareketi sarsacak kadar kuvvetli bir sarsıntıya sebep olmuştur. Çaresiz 
kalan İttihadçılar, Cenevre'de toparlanmaya çalışan ve liderliğini Ahmed Rıza'nın yaptığı, İshak Sükûti ve Tunalı Hilmi'nin de aralarında bulunduğu yeni bir teşkilâtlanmaya gitmişlerdir.

Dr. Abdullah Cevdet, Cenevre'ye gelip bu yeni gruba dahil olmuştur (1897). Burada cemiyetin yayımladığı "Osmanlı" dergisinin başyazarı olmuştur. Osmanlı dergisi kanalıyla İstanbul'da yönetime karşı etkin bir muhalefet yürütülmüştür. Dr. Abdullah Cevdet, Kahire'de cemiyetçe çıkarılan "Kanun-1 Esasî" ile Romanya'da yayımlanan "Sada-yı Millet" ve Cenevre ve Londra'da çıkan "Kürdistan" dergilerine "Bir Kürd" takma adıyla rejim aleyhtarı yazılar yazmıştır.

Dr. Abdullah Cevdet, Schiller'in Guillaume Teli'ini tercüme ederek yayımlamıştır (1895). Bu esere yazdığı önsözde, halkı ve aydınları istibdad rejimine karşı harekete geçmeye çağırmaktadır. Bu önsöz daha sonra, "İki Emel" adıyla Kahire'de yayımlanmıştır (1898).

Dr. Abdullah Cevdet, 1897 yılında Fünûn ve Felsefe adlı eserini yayımlamış ve şiirlerini Kahriyat adıyla toplamıştır. Alfieri'nin Della Tirannide adlı eserini "İstibdat" adıyla yayımlamıştır ve Shakespeare'in "Ode" adlı manzumesini çevirmiştir.

Dr. Abdullah Cevdet, Osmanlı dergisinde II. Abdülhamid'in dinî vecibelerini yerine getirmediği için gerçek halife sayılamayacağını iddia etmiştir. Bu yöndeki muhalefetin liderleri arasında yer almıştır. İttihad ve Terakki bu konuda fetvaları, "Fetva-yı Şerife" ve "Mahkeme-yi Kübra" adıyla yayımlamıştır (1895).

1898 yılında Osmanlı dergisi malî güçlükler sebebiyle yayım hayatında zorlanmaya başlamıştır. Malî kaynak sağlayanlar, ya padişahla anlaşıp desteklerini kesmişler ya da padişahın korkusundan destek olamamaktadırlar. Bu arada Dr. Abdullah Cevdet, İshak Sükûti ve Tunalı Hilmi de Padişah ile görüşmelere başlamışlardır. Bu girişimi İttihad ve Terakki de desteklemiştir.

Sonunda anlaşma yapılmış ve bu üç yazar, Padişah aleyhine yazı yazmamak kaydıyla 1500 'er Frank para aldılar ve 15 altın aylık almaya başladılar. Bu aylık ömür boyu olacaktı. Dr. Abdullah Cevdet, Cenevre'den ayrıldı ve Padișah aleyhine yayım durdurmuştur. Buradan Padişah'ın şahsına bir kartpostal yollamıştır. Bu hareket, Osmanlı Hükümeti'nce protesto edilmiş ve Dr. Abdullah Cevdet Almanya' dan sınır dışı edilmiştir. Paris'e giden Dr. Abdullah Cevdet, burada aylığını almaya devam etmiştir. Ancak Paris Büyükelçisi Münir Paşa, Padişah aleyhine yazı yazmayı gizlice sürdürdüğünü tespit edince tahsisatını kestirmiştir. $\mathrm{Bu}$ dönemde Dr. Abdullah Cevdet halk ve cumhuriyet üzerine yazılar yazmaktadır. $\mathrm{Bu}$ yazılar tedirginliği, padişah cephesini tekrar anlaşmaya zorlamıştır. Cenevre'ye gelen Abdullah Cevdet, sarayla anlaşarak 15.000 Frank yıllık ile Viyana Büyükelçiliği resmî hekimi olmuştur. Dr. Abdullah Cevdet'i, Büyükelçi Karatodori ikna etmiştir. Ancak bu hareket, İttihatçılar tarafindan ihanet olarak kabul edilmiştir. Bu arada İshak Sükûti de Roma Büyükelçiliği hekimi ve Tunalı Hilmi de Madrid Büyükelçiliği'nde kâtip olmuştur (1889). Önceleri ihanet etmediğini belirtmek için maaşlarını teşkilâta yollayan Dr. Abdullah Cevdet, bundan vazgeçince bir kez daha ihanet ile suçlanmıştır. Yazı yazmayacağına dair belge imzaladığı halde, Osmanlı dergisine imzasız yazı yollaması devam etmiştir. Bu sırada 
şiirle uğraşmış ve Avrupa'da seyahatler yapmıştır.

Dr. Abdullah Cevdet'in siyasî faaliyetlerini gizlice devam ettirdiğini fark eden Viyana sefiri Mahmud Nedim, bunu eleştirince sefire karşı fiilî tecavüzde bulunmuştur. Bunun üzerine Büyükelçilik polise başvurmuş ve sınır dışı edilme kararı Avusturya hükümetince alınmıştır. Parlamenter Pemerstorfer'in gayretlerine rağmen Avusturya'dan çıkarılmıştır (1903). Pressburg'a giden Dr. Abdullah Cevdet, padişaha affı için başvurmuş ve kabul edilmeyince Paris'e gitmiştir. Burada Ahmed Rıza tarafından ihanetle suçlanmış ve İttihatçıların arasına alınmamıştır.

Viyana döneminde Dr. Abdullah Cevdet, "Memoire Presentee au Congres International de 1'Education Sociale" (1900), La Lyre Turque (1901),

Les Quatre Trains Maudits et les Âmes Orpheline (1903), Hakkı Tedib (1903, yayımı 1912), Chillon Mahpusu (tercüme 1899), Droit d'Asile en Suisse (1904), Hükümdar ve Edebiyat (1903), Le Bonn'dan Ruh'ül Akvam tercümesi (1900, 1903, 1913), Hamlet (1902) adlı eserleri yayımlanmıştır.

Cenevre'de Edhem Ruhî (Balkan) ile buluşan Dr. Abdullah Cevdet, Osmanlı dergisini yayımlamaya başlamışlardır. Mart 1904'te Cenevre'de Osmanlı îttihad ve İnkılâp Cemiyeti'ni kurmuşlardır. Bu arada Ahmed Celâleddin Paşa'nın maddî yardımıyla 1904'te İctihad dergisini kurmuştur. Bu dergi, İttihadçı hareket içinde ansiklopedist ve kültüre önem veren yegâne dergi olmuştur.

Dr. Abdullah Cevdet, 1904'te "Bir Rüya" adlı Abdülhalim Hikmet adlı saray casusunun provokatör nitelikli eserini bastığı için 1904'te İsviçre'den kovulmuştur. Osmanlı dergisi kapanmış ve İctihad'ın yönetimi Hüseyin Tosun'a intikal etmiştir. 1905'te İstanbul'da gıyabında yargılanan Dr. Abdullah Cevdet, ömür boyu kalebentlik cezasına çarptırılmıștır.

1905 'te Misır'a giden Dr. Abdullah Cevdet, Kahire'de îctihad'1 yayımlaya devam etmiştir. Bu sırada Prens Sabahaddin'in grubuna katılarak, Şurâ-yı Osmanî teşkilâtı içinde yer almıştır. Osmanlı hanedanına gerek olmadığı yolundaki yazıları İttihatçıları dahi infiale sürüklemiş̦tir. 1905-1911 yılları arasında Kafkasya'da Müslümanlara Beyanname (1905), Kahriyat II (1904), Ey Zillullah! Sana (1900), Dozy'nin “İslâmiyet Tarihi “tercümesi (1908), Daubrause'nin "Musikî ve Tedavi”" tercümeleri (1904), "Macbeth" ve "Julius Caesar" (1904) tercümeleri, Emile Boutmy'nin "Essai d'une Psychologie du Peuple Anglais" adlı eserini "İngiliz Kavimi" adıyla tercümesini (1909) ve "Yaşamak Korkusu" (1909) yayımlamıştır.

Dozy'nin "İslâm Tarihi" adlı eserinin tercümesi yayımlanınca, bu eserde Hz. Peygamber'in hayatının marazi psikoloji ile açıklanması din düşmanı olarak tanınmasına yol açmıştır. Birçok eleştiri yazılmasına sebep olmuştur. Meşihat makamına yapılan şikâyetler sonucu, 17 Şubat 1910'dả Bakanlar

Kurulu kitabı yasaklamış, toplatılanların Galata köprüsünden denize atılmasına karar vermiştir.

1910 yilı sonunda İstanbul'a dönen Dr. Abdullah Cevdet, iktidardaki İttihatçılardan 
ilgi görememiş, dinci muhalefetin tepkisi ile karşılaşmış ve 1911 'de İctihad' 1 İstanbul'da çıkarmaya başlamıştır. Burada "İctihad Evi”"ni kurmuştur (1911). Aslında Dr. Abdullah Cevdet, İttihad ve Terakki Cemiyeti'nin kurucularından biri olarak, 1908 ihtilâlinden sonra hemen İstanbul'a dönüp, yeni yönetimde yer alamaması oldukça anlamlıdır. Zira Dr. Abdullah Cevdet'in İttihad ve Terakki'ye dahil ettiği Ziya Gökalp gibi İttihadçı liderlerin ve tümünü tanıdığı İttihadçı kadronun ilgisini çekememiştir.

Dr. Abdullah Cevdet'in Meşrutiyet sonrası ilgi görmemesinin başlıca sebebi, Avrupa'daki faaliyetleri olsa gerektir. Birçok araştırmacı, bunun sebebini, Avrupa'da iken padişah ile anlaşmasına bağlamıştır. Ancak bize göre bu yeterli bir sebep değildir. Zira Tunalı Hilmi, İshak Sükûti gibi birçok başka İttihadçı da padişah ile anlaşmıştır. Dr. Abdullah Cevdet'in ilgi görmemesinin sebebi, karakterinden kaynaklanmaktadır. Çok geçimsiz ve para konusunda aşırı tutumlu olması, en yakın arkadaşlarını bile kırmaktan çekinmemesi ve vefa duygusunun zayıf olması, Dr. Abdullah Cevdet'i önderi olduğu İttihadçı hareket içindeki lider rollerinden uzak tutmuştur. Bu sebeple, kurucusu olduğu İttihad ve Terakki'nin iktidar yollarında iktidardan uzak kalmıştır. Mısır'da iken Prens Sabahaddin'in Adem-i Merkeziyetçileri ile ilişkisi, İttihatçılardan iktidarı ele geçiren Talat-Enver-Cemal triumvirasının şüphesini çekmiştir. 1913'te Mahmud Şevket Paşa suikastı sebebiyle, İttihad ve Terakki içindeki Prens Sabahaddinci muhalefeti de tepeleyen bu üçlü, Dr. Abdullah Cevdet'e şüphe ile yaklaşmışlardır. Zaman zaman İctihad'a malî desteklerde bulunsalar da, Dozy'nin “İslâmiyet Tarihi”ni çevirip yayınlaması, İslamcılar ile arasını açmıştır. Bundan sonra İslâmcılar ve din uleması ile bitip tükenmek bilmeyen bir polemik başlamıştır. İslamcılar, Dr. Abdullah Cevdet'i defalarca şikâyet ederek İctihad'1 kapattırmışlardır. Sonunda örfì idare, Birinci Dünya Savaşı esnasında İctihad'ı tatil etmiştir.

Dr. Abdullah Cevdet, İttihad ve Terakki iktidarından beklediğini bulamayınca, muhalefete başlamıştır. İlginçtir ki, bu muhalefette dövüştügü İslâmcılarla da zaman zaman işbirliği yapmaktan çekinmemiştir. 1910 yılında kurulan Osmanlı Demokrat Fırkası'nın Başkan yardımcısı olunca, İttihatçılarla yolu iyice ayrılmıştır. Bu partinin yayın organı olan "Genç Türk, "Selâmet-i Umumiye", "Azad" ve "Türkiye" gazete ve dergilerine yazılar yazmıştır. Bu parti daha sonra Hürriyet ve İtilâf Fırkası ile birleşmiştir.

Dr. Abdullah Cevdet, İstanbul'a döndükten sonra, "Fenn-i Ruh" adlı eserini (1913), Weber'in "Asırların Panaroması"nm tercümesini Gustave Le Bonn'un "Les Aphorismos des Temps Presents" adlı eserini "Asrımızın Nusus- 1 Felsefesi" adıyla tercümesini yayımlamıştır. Ayrıca Rıza Tevfik ile birlikte Ömer Hayyam'ın “Rubaiyyat”ını çevirip neşretmiştir (1914). Daha sonra Gustave Le Bonn'dan "Enseigment Psychologique de la Guerre Europeene” adlı eserini “Avrupa Harbi’nden Alınan Psikolociyaî Dersler" adıyla çevirmiştir.

Dr. Abdullah Cevdet, İslâmcılar ile mücadelesi sebebiyle çok sıkıntı çekmiştir. İctihad, Şeyhülislâmlık, Adliye Nezareti ve Babıali'ye yapılan müteaddit başvurular ile defalarca kapatılmıştır. 1913'te Cehd adıyla, daha sonra da İşhad, İştihad ve Alem-i Ticaret ve Sanayii adlarıyla yayımlanmıştır. Illk olarak 28 Mart 1913 'te kapatılmıștır. Sonra 6 Nisan 1913 'te İctihad adıyla, 6 Nisan 1913'te Cehd adıyla, 27 Eylül 1913 'te İşhad adıyla yayımı durdurulmuştur. 16 Ekim 1913'te adi ne olursa olsun S1kıyönetimce toplatılmasına karar verilmiştir. 30 Aralık 1913 'te tekrar kapatılmıştır. 
Dr. Abdullah Cevdet, üzerinde yoğunlaşan baskılar sebebiyle yurtdışına kaçmak istemiştir. Bu amaçla rejim muhaliflerinin toplandığı İsviçre'ye sığınmak istemişse de daha önce İsviçre'den sınır dışı edildiğinden İsvf́çre Hükümetince reddedilmiştir (1912). Bu yüzden mevcut İttihad ve Terakki Cemiyeti'nin yayın organı olan Halk Gazetesinde başyazarlık yaparak, iktidarla ilişkilerini düzeltmeye çalışmıştır (1912). Ancak bu çabası da başarılı olamamış, mevcut iktidarı tenkitten vazgeçememiştir.

1912 yılında İctihad'da bir rol ayırımı olmuştur. İctihad'ın önemli yazarlarından Kılıçzâde Hakkı ve Celal Nuri ile Dr. Abdullah Cevdet' in yolları ayrılmıştır. Dr. Abdullah Cevdet, Balkan yenilgisinden sonra tek kurtuluş reçetesi olarak, Batıdan her şeyin tamamen alınmasını, Batı ile aynılaşmayı, tam Batıcılığı savunmaya başlamıştır. Celal Nuri ise buna karşı çıkmış ve öz değerlerin muhafazası yoluyla kısmî bir Batıcılığı savunmuştur. Bu ise Batıcılar arasında iki grubun oluşmasına yol açmıştır. Bunlar tam Garpçılar ve kıs̉mî Garpçılardır. Dr. Abdullah Cevdet, tam Garpçıların lideri konumuna yükselmiştir.

İctihad, 13 Şubat 1915 yılında yayımını durdurmuştur. Zira Dr. Abdullah Cevdet, iktidarı eleştirirken dozu kaçırınca İttihadçılar tarafından ölümle tehdit edilmiştir. 19151918 yılları arasında sessiz kalan Dr. Abdullah Cevdet, 30 Ekim 1918' de imzalanan Mondros Ateşkes Antlaşmasından sonra yazılara başlamıştır. Mart-Haziran 1918 tarihlerinde İkdam gazetesine imzasız yazılar yazmısssa da, durumun İttihadcılarca haber alınması üzerine yazıları kesmiştir.

Dr. Abdullah Cevdet, Shakespeare'in Kral Lear adlı eserini 1917'de tercüme edip yayımlamıştır. Ateşkes ilânı ile siyaset sahnesine dönen Dr. Abdullah Cevdet, 1 Kasım 1918"de İctihad'ı yeniden yayımlamıştır. Ancak İctihad, bu dönemde Batıcılıktan çok İttihadçı düşmanlığı yapmaktadır. Dr. Abdullah Cevdet, Serbesti ve Türkçe Yeni İstanbul gazetelerinde bu düssmanlığı sürdürmektedir. Bu arada İngiliz Muhipleri Cemiyeti’nin nizamnamesini hazırlayanlar arasında yer almıştır. Ancak üye olmamıștır. Ancak bu durum ileride muhaliflerince kullanılmıştır. Kürt Teali Cemiyeti'nin faaliyetlerine katılmış, ancak etnik ayırımeılık mahiyetinde Kürtçülük yapmamıştır. Daha önce Meşrutiyet devrinde "Roj-1 Kürd" ve "Hetav-1 Kürd" dergilerine yazdı̆̆ı gibi, Mütareke döneminde de "Jin" dergi ve gazetesinde aynı görüşleri savunmuştur. Bu sebeple İngiliz mandası altında özerk Kürdistan hayali ile yaşayan Kürtçülere de yaranamamıştır.

30 Mart 1919'da Sihhiye Umum Müdürü olmuştur. Ancak İctihad'da çıkan yazılar, dini zayıflatıcı olarak nitelendirilince beş ay sonra azledilmiştir. Ancak Hürriyet ve İtilâf hükümetince 20 Mayıs 1920'de tekrar aynı göreve atanmıştır. Yine beş ay sonra azledilmiştir. İctihad, dini tezyif ettiği için 10 Mart 1919 'da kapatılmıştır. Defalarca kapatılan dergi yayımını durdurmak zorunda kalmıştır. Bu arada Dr. Abdullah Cevdet, Yirminci Asır adlı gazetede yazı yazmiştır.

Dr. Abdullah Cevdet, İctihad' da İslâmiyet yerine yeni bir din olarak Bahaîliği önerince hakkında dava açılmıştır. 20 Nisan 1922' de iki yıl hapse mahkum edilmiştir. Dava temyizce bozulmuştur. Dava ancak 30 Aralık 1926'da peygamberlere fena ifade kullanmanın Ceza kanunundan çıkarılması ile düşmüştür.

23 Kasım 1922 'de yeniden yayımlanmaya başlayan İctihad, İstiklâl Harbi'ni 
methetmektedir. Mustafa Kemal ve İsmet Paşa'yı öven yazılar çıkmıştır. Ancak bu tavır, işgal dönemindeki tutumu, Kürtçü ve İngiliz yanlısı hareketleri ile mimlenen Dr. Abdullah Cevdet' in Âlî Heyetçe kamu hizmetinden yasaklanmasına engel olamamıştır. Dr. Abdullah Cevdet, yaptı̆̆ itirazlardan sonuç alamamıştır.

1924 yılının Aralık ayında boşalan Elazı ̆ milletvekilliği için Mustafa Kemal Paşa tarafından Ankara'ya çağırılmıştır. Ancak Dr. Abdullah Cevdet, bu firsatı iyi değerlendirememiştir. Zira Mustafa Kemal Paşa, iyi bir îctihad okuruydu. Ancak dinci basın, Anadolu'daki nüfus politikası ile ilgili değişik görüşlerini Avrupa'dan damızlık erkek celbi olarak kamuoyuna sununca, milletvekilliğinden vazgeçilmiştir. Bundan sonra Abdullah Cevdet'in iktidarda mevkii talebi veya bu yönde-kendisine bir teklif olmamıştır.

1923-1932 dönemi. Dr. Abdullah Cevdet için acı bir dönemdir. Zira daha önce savunduğu kadın hakları, laiklik, Latin alfabesi gibi Batıcı adımların birer birer devrimler olarak atıldığını görmekte, ancak bunların uygulanışında rol alamamaktadır. Bu durum, Dr. Abdullah Cevdet içe kapanmasına ve kendini ilmi yayınlara adamasına yol açmıştır. Gustave Le Bonn'un «Hier et Demain»1 «Dün ve Yarın» ve «Psychologie des Foules»1 «Illm-i Ruh-1 İçtimaî̀ (1924) adıyla yayımlanmıştır. Baron Motom'un L'Oeuvre de Gustave Le Bonn adli eserini çevirmiştir. Ömer Beyse'den "Amerika Tibbiye Usûlleri” (1926), Jean Marie Guyau'dan "Terbiye ve Veraset"i (1926), Novicow'dan "Harp ve Sözde İyilikler" (Çevriliş 1915, yayımı 1925), Rahip Meslier'den "Le Bonn Sens"i “Akl-1 Selim" (1926) adıyla çevirmiştir. Guyau'nun "Bir Filozofun Şiirleri" (1929) ve Le Bonn'un “Amelî Ruhiyat"ını (1931) çevirip yayımlamıştır.

1932 yılında 63 yaşında iken İctihad Evi'nde geçirdiği bir rahatsızlık sonucu hayata gözlerini kapamıştır. Ölümü üzerine İctihad 358 sayısı ile yayın hayatını tamamlamıştır.

Dr. Abdullah Cevdet, kelimenin tam anlamıla bir muhalifti. Önce II. Abdülhamid'e, sonra Meşrutiyeti ilân eden İttihadcılara muhalefet etmiştir. Hayatı maceralı bir biçimde geçmiştir. En istikrarlı yanı, 1904-1932 yılları arasında 28 yıl ve 358 sayı yayımlanan, İctihad dergisidir. Bu dergide, kitap ve diğer makalelerinde tam Garpçılığı hiç durmadan savunmuştur. Son dönem Osmanlı aydınlarının tipik örneklerinden biri olan Dr. Abdullah Cevdet, tam Batıcılık ile Cumhuriyete ışık tutmuştur.

\section{DR. ABDULLAH CEVDET'IIN ESERLERI}

\section{-Telif Eserleri:}

-Hiç, Mahmud Bey Matbaası, İstanbul, 1307 (1889), 24 af.

-Dimağ: Dimağ ile Ruh arasındaki Münasebat-1 Fenniyeyi Tedkik, Sahib ve Naşiri Vatan Kütüphanesi Sahibi Ohannes Ferid, İstepan Matbaası, Ístanbul, 1308 (1890), 46 sf,

-Fizyolociya-i Tefekkür: Mehazımın Esası C (K) raft und Stoff Unvanlı Kitabın Tefekkür Bahsidir, İstepan Matbaası, İstanbul, 1308 (1890), 72 af

-Ramazan Bağçesi: Tabi’ ve Naşiri Ohannes Ferid, Dersaadet, 
$1308(1890), 29 \mathrm{sf}$

-Tulûat, Alem Matbaası, İstanbul, 130 S (1890), 80 af

-Türbe-i Ma'sumiyet, Sahib ve Naşiri Vatan Kütübhanesi Sahibi Ohannes Ferid. İstepan Matbaası, İstanbul, 1308 (1890), 36 sf ..

-Fünûn ve Felsefe, Tarih-i Tesvid, 1309 (1891), Taş Basma, (Cenevre), (1897), 31 sf

-Ma'sumiyet, İstepan Matbaası, İstanbul, 1311(1893), 45 sf.

-Fizyolociya ve Hıfz-1 Sihhat-i Dimağ,ve Melekât-1 Akliye, Mahmud Bey Matbaası, Dersaadet, 1312, 232 sf

-Mahkeme-i Kübra, Taş Basma (Paris), 1313(1895), 21 sf. (Tab'-1 Sani, Matbaa-i İctihad, Misir, 1908)

-Ulema-yı İslâm Enarallahu Berahinuhum Tarafından Verilen Fetva-yı Şerife, (Fetvalar Şakir Hoca tarafindan verilmiștir), Tab'-1 Sani, Matbaa-i İctihad, Misır, 1325, 22 af. (Illk Baskı Meşveret Matbaası, Cenevre, 1314 (1896). 64 af.

-Kahriyat (I), Osmanlı İttihad ve Terakki Cemiyeti Matbaası, (Cenevre), 1315 (1897),

-İki Emel, Osmanlı İttihad ve Terakki Cemiyeti Matbaası, Misır-el-Kahire, 1316 (1898), 32 sf. (İkinci Baskı, Misır 1906; 3.Baskı, İstanbul 1912; 4.Baskı,

İstanbul, 1914)

-De La Necessite d'Une Ecole Pour les Educateurs Sociaux: Memoire Presente au Congres interaational de l'Education sociale, Tenu a l'Exposition üniverselle de Paris du, 26 au 30 Septembre 1900, Paris, 1900, 40 af.

-Fievre d'âme, Paris-Vienna, 1901, 132.

-İklil-i Matem, Taş Basma (Viyana), 1901, 27 sf.

-Elegie, Vienna, 1902, 1 sf.

-La Lyre Turque, Paris-Vienna, 1902, 187 sf.

-Über die Erziehung der Lehrér, Almanca'ya Tercüme:

Eisenschiml, Wien, 1902, 48 af.

-Hadd-1 Te'dib Ahmed Rıza Bey'e Açık Mektub, Tab'-1 Sani, 
Naşiri: İzmirli Mehmed Şükrü, Matbaa-i İctihad, İstanbul, 1912, 72 af. (Ilk Baski Paris 1903) sf.

-Les Quatrians Maudits et les reves orphelins, Libraire de la Plume, Paris, 1903,173

-Reponse au Journal de Geneve (Cenevre), 1904, 2 af.

-La Vengeance Doree, Imprimerie Internationale, Geneve, $1904,26 \mathrm{sf}$

-Droit d'Asile en Suisse, Imprimerie Internationale, Geneve, 1905,74 af

-Rafale de Parfums, Imprimerie Internationale, Geneve, 1905, 132 sf.

-Fünûn ve Felsefe (2), Matbaa-i İctihad, Misır, 1906, 49 sf

-İkaz-1 Müslim, (Muhammed Ghuri'den uyarlama), Matbaa-i İctihad, Misır, 1906, $157 \mathrm{sf}$.

-Kahriyat (2), Matbaa-i İctihad, Misır, 1906(1908), 128 sf.

-Uyanınız! Uyanınız!, Matbaa-i İctihad, Misır, 1907, 36 sf. (İkinci Tab: 1908 Mısır)

-Viola Semper Florens: Sonnets, Imprimerie Internationale, Caire, 1908, 79 sf.

-Yaşamak Korkusu, Kütübhane-i Cihan, İstanbul, 1326 (1908),

$24 \mathrm{sf}$

-Bir Hutbe Hemşehrilerime, Matbaa-i İctihad, Mısır, 1909,16 sf.

-İstanbul'da Köpekler, Matbaa-i İctihad, Mısır, 1909,16 sf.

-Fünûn ve Felsefe ve Felsefe Sanihaları, Matbaa-i İctihad, İstanbul, 1328 (1910)

-Fenn-i Ruh: Dimağ ve Ruh-Tefekkür-Vicdan-Dimağ ve Tefekkür, Matbaa- i İctihad, İstanbul, 1911, 136 af.

-Dimağ ve Melekât-1 Akliyenin Fizyolociya ve Hifzissihhası, Matbaa-i Amire, İstanbul, 1333(1914) - 1335(1916) (Diş Kapakta 1335-1337), 478 sf. 
-Discours pronoflcé le 20 Août 1920 par le Dr. Abdullah Djevdet Bey, Directur Général de l'Office Sanitaire, â l'inauguration de l'hôpital Américain fondé récomment â Tcarchi-Capou, İstanbul, 1920, 1 sf.

-Cihan-1 İslâma Dair Bir Nazar-1 Tarihi ve Felsefi, Necm-i İstikbâl Matbaası, İstanbul, $1922,32 s f$.

-Mükemmel ve Resimli Adâb-1 Muaşeret Rehberi, Yeni Matbaa İstanbul, 1927, 523 sf

-Muhtelif İzdivaçlar, İstanbul, 1928, 4 sf.

-Karlı Dağdan Ses, İctihad'ın Kitapları, Orhaniye Matbaası, İstanbul, 1931, 183 sf.

-Düşünen Musikî, İctihad'ın Kitapları, İstanbul, 1932, 34 sf.

-Tercüme ve Deneme Eserleri

-Ludwig Büchner, Goril (Natur und Geist), Matbaa-i Vilayet (Mamuret-el- Aziz), 1311(1893), 57 af.

-(Johann Friedrich Von) Schiller, Guillaume Tell, Typo-lith. A.Costagliola, Misir-elKahire, 1314 (1896), 165 af.

-William Shakespeare, Ode, Taş Basma, Cenevre, 1898, 1 sf.

-Alfieri, V., İstibdad (Della Tyrannia), Osmanlı ittihad ve Terakki Cemiyeti Matbaası, Cenevre, 1317(1899), 314 sf. (İkinci Baskı, Matbaä-i İctihad, Mısır, 1908, Dış Kapak 1909)

-Lord Byron, Chillon Mahbusu (The Prisoner of Chillon), Matbaa-i İctihad, Cenevre, 1904,38 sf.

-Alfieri,V., Hükümdar ve Edebiyat (Del principe e delle lettere), Matbaa-i İctihad, Cenevre, 1905 (Dış Kapak, Misır 1906), 336 af.

-Gustave Le Bonn, Ruhü'I-Akvam (Les lois psychologiques de l'Evolution des Peuples), Matbaa-i İctihad, Misır 1907, 308 sf- (2. Baskı Matbaa-i İctihad, İstanbul 1913)

-R(einhardt) Dozy, Tarih-i İslâmiyet (Essai sur l'histoirede 1 'Islamisme), Cild-i Evvel, Matbaa-i İctihad, Misır, 1908, 334 sf., Cild-i Sanî, Matbaa-i İctihad, Misır, 1908 (1909), 388 sf.

-William Shakespeare, Hamlet, Matbaa-i İctihad, Misır, 1908,44 af.

-William Shakespeare, Julius Caesar, Naşiri: Kütübhane-i Cihan, Sahibi Mihran, Matbaa-i İctihad, Mısır 1908 (Diş kapak: Matbaa-i Cihan, Dersaadet 1909), 165 af.

-Emile Boutmy, Ingiliz Kavmi (Essai d'une Psychologie Politique du Peuple Anglais), 
Kitab-1 Evvel, Matbaa-i İctihad, Mısır, 1909, 100 sf., Dördüncü Kitab, Matbaa-i İctihad, İstanbul, 1912, 387 sf.).

-William Shakespeare, Macbeth, Matbaa-i İctihad, Misır, 1909,159 s£.

-Sanfani, T1bbiyeli ve Nişanlısı Yahud Mekârim-i Ahlâkiyesiz Din, Dinsiz Mekârim-i Ahlâkiye (Baskıya Hazırlayan. Abdullah Cevdet), Naşiri: İkbal Kütübhanesi Sahibi Hüseyin,Vilâyet Matbaası, İstanbul, 1928 (İlk Baskı, Matbaa-i İctihad, Mütercim. A.Vefa, İstanbul 1329 (1911), 64 sf.).

-J(Z). Weber, Asırların Panoraması Yahud Tarih-i Kainata Bir Nazar, Matbaa-i İctihad, İstanbul, 1913, 236- II sf.

-Gustave Le Bonn, Asrımızın Nusus-u Felsefiyesi (Les aphorismes du temps présent), Matbaa-i İctihad, İstanbul, 1914, 184 sf.

-Ömer Kayyam, Rubaiyat-1 Hayyam ve Türkçe'ye Tercümeleri, 2.

Tab’, Naşiri: İkbal Kütübhanesi Sahibi Hüseyin, Matbaa-i Şirket-i Mürettibiye, İstanbul, 1926, 454 sf. (İlk baskı: İstanbul 1914, 88 sf.)

-William Shakespeare, Kral Lear, Kütübhane- i İctihad, 1917, 190 sf.

-Gustave Le Bonn, Avrupa Harbinden Alınan Psikolociyaî Dersler, (Enseignements psychologiques de la guerre eurapéenne), Naşiri: İlyas, Kanaat Matbaası, İstanbul, 1918, $715 \mathrm{sf}$.

-Mevlana Celâleddin-i Rumî, Dilmesti-i Mevlana, Matbaa-i İctihad,

Orhaniye Matbaası, İstanbul, 1921, 128 sf.

-William Shakespeare, Antuan ve Kleopatra, Tabi ve Naşiri: Aktör Hüseyin Vedad, Matbaa-i Necm-i İstikbâl, İstanbul, 1921, 223 sf.

-Gustave Le Bonn, Dün ve Yarın, (Hier et demain), Orhaniye Matbaası, İstanbul, 1924,264 sf.

-Gustave Le Bonn, İlm-i Ruh-u İçtimaî (Pschologie des Foules), Âmedî Matbaası, İstanbul, 1924, $287 \mathrm{sf}$.

-(Voltaire), Rahip Meslier'nin Vasiyetnamesi Hakkında, (Testament de Jean Meslier), Tabi ve Naşiri: Cemiyet Kütüphanesi, Necm-i İstikbal Matbaası, İstanbul, 1924, 64 sf.

-Omer Buyse, Umumî ve Âli Amerika Terbiye Usul 1 eri, (Methodes Américaines d'Education générale et technique), Matbaa-i Amire, İstanbul, 1925-1926, Cild: I-III, $610-384-381$ sf. 
-Le Baron Motono, Bir Zekâ-i Feyyâz, (L'Oeuvre de Gustave Le Bonn, Necm-i İstikbâl Matbaası, İstanbul, 1925.

-Jean-Marie Guyau, Terbiye ve Veraset, (Education et Hérédité), Millî Matbaa, İstanbul, 1927, 560 af.

-J(acques) Novicow, Harp ve Sözde İyilikleri, (La guerre et ses prétendus bienfaits)Orhaniye Matbaas1, İstanbul, 1927, 319 sf.

-(Baron Holbach), Akl-1 Selim, (Le bon sens ou Idées naturel- les opposées aux idées sumaturelles, Şirket-i Mürettibiye Matbaası, İstanbul, 1928, 536 sf. (Tabi ve Naşiri Dr. Abdil Hüsnü), İkinci baskı, Devlet Matbaası, İstanbul, 1929, 548 sf..

-Jean-Marie Guyau, Bir Filozofun Şiirleri, (Vers d'un philosophe ), Devlet Matbaası, İstanbul, 1930,262 af.

-Gustave Le Bonn, Amelî Ruhiyyat, (Les aphorismes du temps presence), İctihad'in Kitabları, İstanbul, 1931, 223 sf. (24)

\section{B- İCTIHAD DERGISI}

Îctihad Dergisi'nin 28 yıl süren yayın hayatı boyunca binlerce sayfa süren malzemesinin tetkikini yaparken en büyük problem hiç kuşkusuz makalelerin seçim konusu olmuştur. Zira her makale, halkı aydınlatma ve okuyucuyu şuurlandırma amacıyla kaleme alındığı, yeni bir hayat modeli olarak Batıcılığı önerdiği için büyük kıymeti haizdir. Ancak bir Doktora tezinin kapsamında bunların her birinden sadece birer cümle ile bahsetmek bile büyük bir yekûn tutacaktır. Lewis, "Ortadoğu” adlı eserinin önsözünde "Zengin, değişken ve canlı bir belgenin iki bin yıllık tarihini bir cilt içinde vermek, onun taşıdığı önemin büyük bir kısmını göz ardı etmektir. Bölgeyi araştıran her araştırmacı bu konuda kendi seçimini kendi yapar. Bende kaçınılmaz olarak kişisel olan kendi seçimimi yaptım. En karakteristik bulduğum olaylara, en öğretici kişilere, olaylara, eğilimlere ve başarılara gerekli önemi vermeye çalıştım. Bunda ne kadar başarılı olduğuma okur karar verecektir" ${ }^{\prime 5}$ diye yazmaktadır. Tezimizde de benzer bir metot izlenmiştir.

Dr. Abdullah Cevdet, İctihad'ın yayımlanması münasebetiyle kaleme aldığı yazısında, İctihad'ın İsviçre' de yayıma başladığını belirterek, dergide yayımlanan yazı ve fikirlerden yalnızca yazarların sorumlu olduğunu, İctihad'ın çeşitli görüşlerin arenası olarak düşünüldüğünü, bu ortamın Osmanlı ülkesinde mevcut olmaması sebebiyle İsviçre'de yayıma başlandığını yazmaktadır. ${ }^{16}$

Dr. Abdullah Cevdet, İctihad dergisinin her çeşit fikrin yayınlanabileceğini, hatta birbirine tamamen zit olan fikirlerin bir arenası olduğunu söylemektedir. Birçok yazı, birbirine muhalif niteliktedir. Dr. Abdullah Cevdet, bunun tabii olduğunu, ancak bazılarının

Y

15 Lewis, bkz. 2000, VII

16 Abdullah, Cevdet, bkz. 1940b, 1-2 
bu durumu anlamadığını söylemektedir. ${ }^{17}$ ânlatmıştır:

Dr. Abdullah Cevdet, îctihad'ın yayımlanış hikayesini İctihad'ın 158. sayısında

“Ben 'İctihad' matbaasını İsviçre'nin 'Cenevre' şehrinde 'Rue Roseraie No:2'de tesis ettim. Yalnız İctihad mecmuasını ve İctihad Kütüphanesi kitaplarını tab' etmekle koca bir matbaa meşgul ve muammer olamazdi; hariçten şehir işleri, ticaret-i evrak matbaası da yapmak lazım idi. Bizim orada hükümetimiz yoktu. Hükümetimizin oradaki mümessilleri de, hükümet matbaalarından aldıkları talimat mucibince mümkün olduğu kadar imhamıza memur idi. Biz bu halde himâyeyi ve müdafaa-ı nefsî, işlerimizin temizliğinden, vaad ettiğimiz zamanda siparişi teslim edebilmekten ve yerli matbaalarından yüzde on ve hatta yirmi nispetinde ucuz yapmaktan bekleyebilirdik. Böyle yaptık ve bu sayede yüzlerce yerli matbaa arasında yaşadık. 'Adab ve Usul-i Muaşeret' adlı bir kitaba yazdığım uzun bir mukaddime de söylediğim veçhile iyinin yegâne ve hakikî rakibi daha iyidir. Ucuzun da yegâne ve hakikî daha ucuzdur." 18

İctihad Dergisi, içindeki yazılardan anlaşılacağı üzere ansiklopedik bir özellik taşımaktadır. Çok çeşitli konularda çok değişik bilgileri ihtiva eden İctihad, okuyucuyu bilgilendirmeyi amaç edinmiştir. Buradan hareketle İctihad'a yazı yazan ve İctihad yayınlan arasında kitapları yayımlanan yazarları, M. Naci ansiklopedist olarak kabul etmektedir. ${ }^{19}$

İctihad Dergisi'nin 1. sayısı, Cenevre'de 1 Eylül 1904'te 17 sayfa olarak Matbaa-1 İctihad tarafından Abdullah Cevdet'in idaresinde yayımlanmıştır. Derginin aylık olduğu belirtilmektedir. 2. sayı Kanun-i Sani 1905 'te Dr. Abdullah Cevdet' in Cenevre'den sinır dışı edilmek istenmesi sebebiyle 2 ay gecikmeli olarak yayımlanmıştır ve 16 sayfadır. 3 . sayı, Şubat 1905 'te 16 sayfa; 4 . sayı, Mart 1905 'te 17 sayfa olarak yayımlanmıştır. 4. sayıda, derginin idaresinin Hüseyin Tosun'a verildiği açıklanmış ve o güne kadar l'den başlayan dergi sayfaları, 5. sayıdan itibaren 65 'ten başlatılarak devam ettirilmiştir. 9. sayıda, matbaa Kahire'ye nakledilmiştir. 9. ve 10. sayılar gecikmeli olarak birlikte çıkmıştır. 13. sayıda yeniden dergi 1. sayı olarak yayımlanmış ve bu durum, 11 sayı devam etmiştir. 13. sayı bütün aramalara rağmen bulunamamıştır. 9 (21). Sayı, 1909 tarihli olup, tarihi yanlıştır. İlk 23 sayı aylık olup, Rumî değil Miladî olarak tarihlendirilmiştir. 8. sayıda Kanun-i Esasî'nin ilânına yönelik şenliklerden bahsedilmektedir.

İctihad Dergisi, 24. sayıdan itibaren 15 günde bir yayımlanmaya başlamıștır. Dergi her ayın Miladî 14. ve 28. günü (Rumi 1. ve 15. günü) çıkmaktadır. 24. sayı ile beraber, matbaa İstanbul'a naklolunmuştur. Ancak bu 24. Sayi, kütüphanelerde bulunmamaktadır. 33. sayıda İtalyanların, Trablusgarb'ı işgal etmeleri üzerinde durulmuştur. 49. sayı, 15 günlük gecikme ile 1. Teşrin-i Evvel 1327'de / 14 Temmuz 1911 'de yayımlanmıştır.

İctihad Dergisi, 50. sayıdan itibaren haftalık olmuş ve Perşembe günleri yayımlanmaya başlamıştır. 21 Mart 1329/3 Nisan 1913 tarihli 59. sayı, derginin hükümetçe kapatılmasından

17 Abdullah, Cevdet, bkz. 1329f, 1898

18 Abdullah, Cevdet, bkz. 1923f, 3245

19 M. Naci, bkz. 1329b, 1876-1877 
dolayı Cehd adıyla çıkmış ve yine tatil edilmiștir. 15 gün sonra 4 Nisan $1329 / 17$ Nisan 1913 'te 60. sayı İctihad adıyla yayımlanabilmiștir. 18 Nisan 1329/ 1 Mayıs 1913 tarihli 62. sayıda, müdir-i murahhaslığa Îlhami Safa getirilmiş̧tir. 30 Mayıs 1329/ 12 Haziran 1913 tarihli 68. sayıdaki "Devâ-yı Kati" adlı makaleden dolayı dergi kapatılmıştır. Dergi ancak 27 Haziran 1329/ 10 Temmuz 1913 tarihinde 69. sayı ile tekrar neşriyata başlayabilmiştir.

15 Aralık 1329/ 28 Aralık 1913 tarihli 76. sayıda çıkan "Yunus Hoca" adlı hikaye yüzünden İctihad Dergisi kapatılmıştır. 29 Aralık 1329/ 11 Eylül 1913 tarihli 78. ve 5 Eylül 1329/ 18 Eylül 1913 tarihli 79. sayıları "İshad" adıyla çıkarılabilmiştir. 12 Eylül 1329/25 Eylül 1913 tarihli 80. sayıda Veliahd İzzeddin Efendi ile yapılan bir mülakatın yayımlanması sebebiyle İctihad Dergisi'nin yayımı durdurulmuştur. Dergi, ancak 21 Teşrin-i Sani 1329/ 4 Kanun-1 Evvel 1913 tarihli 81. sayı ile neşriyata devam edebilmiştir.

23 Kanun-1 Sani 1329/5 Şubat 1914 tarihli 90. Sayıdan itibaren 3 sayı boyunca "Iştihad" adıyla yayımlanmıştır.

12. Sayıda 179. sayfadan sonra gelen sayfaya 4 ve 5 numaralan verilmiş, daha sonraki sayfa ise 182 olarak numaralandırılmıştır. 184. ve 185 . sayfalara ise 8 ve 9 numaralan verilmiştir. 12. sayıdan sonra, numaralandırma yeniden başlamış ve sayfa numarası 1 . ołarak gösterilmiştir. 2 (14) sayılı nüsha ise 217 numaralı sayfa ile başlamıştır

6 (18) sayı 352. sayfa ile bittiği halde 7 (19) numaralı İctihad Dergisi, 253. sayfa ile başlamıştır. Bu, muhtemelen bir matbaa hatasıdır. 9 (21) numaralı İctihad'da 332. sayfadan sonra 233. sayfa gelmektedir. 10 (22) numaralı İctihad, 349. sayfadan başlamaktadır.

9 (21) numaralı İctihad ile 10 (22) numaralı İctihad arasında bir tarih değişikliği vardır. 8 numaralı sayı, Haziran 1908 tarihini taşımakta iken, 9 numaralı İctihad, Mart 1909 ve 10 numaralı dergi ise, Temmuz 1908 tarihinde yayımlanmıştır.

İlk çıktığı zaman aylık olan İctihad Dergisi, "Serbest Mecmua-i Osmaniye ve İslâmiye" alt başlı̆g 1,3 numaralı sayıda "Serbest Mecmua-i İslâmiye" ve 9 (21) numaralı sayıda "Serbest Mecmua-i İlmiye ve Edebiye" şekline dönüşmüştür.

24 numaralı sayıdan itibaren 15 günlük çıkan derginin, "Fennî, İçtimaî, Edebî, Siyasî Mecmua" olan alt başlık yazısı, 26 numaralı sayıda "Fennî, İçtimaî, Edebî Mecmua" ve 29 numaralı sayıda "İktisadî, İçtimai, Edebî Mecmua" şeklini almıştır.

50 numaralı sayıdan itibaren, haftada bir gün ve Perşembe günü yayımlanmaya başlayan İctihad'in başlık alt yazısı "Hürriyet-i Fikriyeye Hâdim, Perşambe Günleri Neşredilir, İktisadî, Içtimaî, Edebî Mecmua"dır.

48 ve 49 numaralı dergiler araśnda sebebi bilinmeyen bir gecikme vardır. 58 numaralı sayıda Kılıçzâde Hakkı Bey'in "İlan-1 Harp" adlı makalesi İctihad'ı kapattırmış ve 59 numaralı dergi Cehd adıyla çıkmıştır. Bir hanımın teseddür aleyhindeki bir yazısı yüzünden Cehd de kapatılmıştır. Dergi 21 Mart 1329/ 3 Nisan 1913’ten 4 Nisan 1329/ 17 Nisan 1913 'e dek kapalı kalmıştır. 
68 numaralı dergide yayımlanan Süleyman Nazif'in "Deva-yı Katl" adlı makalesi yüzünden 27 gün yayımı durdurulan İctihad, 69. sayıda tekrar İctihad adıyla çıkmıştır.

77 numaralı sayıda yer alan Kılıçzâde Hakkı'nın "Yunus Hoca" adlı hikayesi yüzünden dergi tekrar kapatılmıştır. Bu sebeple 78, 79, 80 numaralı sayılar "Işhad" adlıyla yayımlanmıştır.

80 numarah İctihad'daki Abdullah Cevdet'in "Veliaht İzzeddin Efendi Hazretleri ile Mülakat" 1 dergiyi iki ay kapattırmış; 90, 91, 92 numaralı sayılar "Iștihad" adıyla yayımlanmıştır.

Server Bedii adı, takma ad olarak haftaname adıyla yayımlanan bölümde önce İlhami Safa, sonra da kardeşi Peyami Safa tarafindan kullanılmıştır.

Orhan Rıza, Orhan Rıza Aktuna değil Dr. Orhan Rıza'dır. Dergideki şiirler Yusuf Ziya Ortaç'a, “Ingiltere'de Gazeteciliğin Sûret-i Tekamülü” adlı makalede ise başka bir Dr. Yusuf Ziya'ya aittir.

Dr. Abdullah Cevdet, İctihad'ın 50. Sayısında yayıma başlayışının dördüncü yıldönümü münasebetiyle kaleme aldığı yazısında İctihad'ın Batıcı düşüncenin sözcüsü olmasından, Meşrutiyetin gelmesi ile beraber Batılılaşmasının gelişiminden bahsetmektedir. İctihad'ın her görüşe açık bir platform olduğu vurgulanmaktadır. ${ }^{20}$

İctihad Dergisi', 264 numaralı sayısına kadar (1928) Arap harfleri ile daha sonra Latin harfleri ile neşredilmiştir. 228 numaralı sayıdan itibaren "sıhhî" ve 235 numaralı sayıdan itibaren "sanâ̂" başlıkları alarak, ana başlığın altında "İlmî, Edebî, İktisadî, Sanaî, Sıhhî Mecmuadır" ibaresini taşımıştır. 200 numaralı sayı, 3909-3924 sayfa numaralı olması gerekirken 3009-3024 şeklinde numaralandırılmış, ancak 201 numaralı sayı 3925. sayfa numarasından başlamıştır. 212 numaralı sayı 4116. sayfa numarası ile bitmesine rağmen, 213 numaralı say1 4113. Sayfa numarası ile başlayıp 4128 sayfa numarası ile bitmiştir. 214 numaralı sayı 4127 sayfa numarası ile başlamıştır. 215 numaralı sayı 4149 sayfa numarası ile başlaması gerekirken 4143 sayfa numarası ile başlamıştır.

219 numaralı sayidaki 4221-4222 sayfa numaralı sahifeler, 4121-4122 olarak numaralandırılmıştır. 224 numaralı sayıda 4302. sahifeye 4402 şeklinde yanlış numara verilmiştir. 235 numaralı sayı, 4478 sayfa numarası ile bitmesine rağmen, 236 numaralı say1 4487 sayfa numarası ile başlamıştır. 252 numaralı sayı, 4802 sayfa numarası yerine 5002 sayfa numarası ile bitmiştir. 259 numaralı sayıda, önceki sayı 4899 sayfa numarası ile bittiği halde, 5000 sayfa numarası ile başlanmıştır. 263 numaralı sayı 5062 sayfa numarası ile bittiği halde 264 numaralı sayı 5079 sayfa numarası ile başlamıştır.

263 numaralı sayının iç kapağında 264 numaralı sayı ibaresi vardır. 264 numaralı sayı ise 265 şeklindeki başlıkla çıkmıştır.

233 numaralı sayıda, “İctihad'ın Tekâmülü” başlıklı yeni değişiklikler duyurulmuştur. 
Buna göre 235. sayıdan itibaren Alişanzâde İsmail Hakkı Bey'in önerisiyle İctihad, "edebiyat, san'at, musiki, sahne hayatı, bibliyografya, dünya ekonomisi, nüfus hareketleri, dünya ilim ve fikir hareketleri ile sağlığın korunmasına yönelik yayın yapacaktır" bilgisi yer almaktadır. 235 numaralı sayıdan itibaren daha önce 16 sahife olan dergi, 24 sahife olarak yayımlanmaya başlamış, 3,5 kuruş olan fiyatı 10 kuruşa çıkmıştır. 244 numaralı sayı ile sahife sayısı tekrar 16'ya indirilmiştir.

İctihad'ın 201-205 numaralı sayılarını Matbaa-1 Amire'de, 206-209 numaralı sayıları Millî Matbaa'da, 210-221 numaralı sayıları Sebat Matbaası'nda, 222-235 numaralı sayıları Orhaniye Matbaası'nda, 236-240 numaralı sayıları Sebat Matbaası'nda, 241-265 numaralı sayıları Kader Matbaası'nda basılmıştır.

200-239 numaralı sayılar, Dr. Abdullah Cevdet' in, 240-265 numaralı sayılar Dr. Abdil Hüsnü'nün denetiminde yayımlanmıştır. 238 numaralı sayıdan itibaren sayfa sayısı $24^{\prime}$ 'ten $20^{\prime}$ ye, 245 numaralı sayıdan itibaren ise, 16'ya indirilmiștir. 265 numaralı sayı 15 gün gecikme ile yayımlanmıştır.

Dr. Abdullah Cevdet, 276 numaralı sayıda derginin edebiyat kısmını Yedi Meş'alecilere bırakırsa da, bu durum sadece iki sayı devam etmiştir. 266-276 numaralı sayılarda, "Türkçe ve Fransızca İlmî, Edebî, İktisadî, Sana'î, Sihhî Mecmua", 277-1 ve 278-2 numaralı sayılarda "Haftalık Fikir ve San'at Mecmuası" ve 279-358 numaralı sayılarda "Türkçe ve Fransızca İlmî, Edebi, İktisadî Mecmua" ibaresi kullanılmıștır. 319 numaralı sayı, 5638 sayfa numarası ile bitmesi gerekirken, 6438 sayfa numarası ile bitmiş, ancak 321 numaralı sayıda hata düzeltilerek 5451 sayfa numarası ile başlamıştır. 354 numaralı sayıdaki 5833,5834 ve 5835 numaralı sayfalar yanlış yerlerdedirler. 5825-5826-5823-5824 şeklinde sıralanmışlardır. 277-1 ve 278-2 numaralı sayılar, l'den 16'ya kadar numaralandırılmıştır. 279 numaralı sayıda eski düzene geri dönülmüştür. 276 numaralı sayı 5198 sayfa numarası ile bitmiştir. 279 numaralı sayı ise 5230 ile başlamıştır. Halbuki 5220 ile başlaması gerekmektedir.

İctihad'ın 272 numaralı sayısında bir şiir haricindeki tüm yazılar Dr. Abdullah Cevdet tarafindan yazılmıştır.

Harf Devrimi münasebetiyle İctihad'ın 266 numaralı sayısının basımı 2 ay gecikmiştir. 266-267-1 numaralı sayılar Şirket-i Mürettebice Matbaasında basılmıștır. 267-276 numaralı sayılar 15 günde bir yayımlanmaktadır. İctihad, 266 numaralı sayıdaki gecikmeyi, Türkiye' de yeterli sayıda Latin harfi bulunmamasına bağlamaktadır. 266 numaralı sayısının Abdullah Cevdet, 267 numaralı sayıdan itibaren 296 numaralı sayıya dek Abdil Hüsnü tarafından çıkarıldığı görülmektedir. 277-1 ve 278-2 numaralı sayılar, 7 günlük süre ile çıkarılmıştır. Sayfa numaraları da her sayı için 1-16'dır. 278-2 numaralı sayı Letafet matbaasında basılmıştır. 279 numaralı sayı 28 günlük bir aradan sonra yayımlanmış ve sayfa numaraları tekrar eskiye dönmüş̧ür. 279-284 numaralı sayılar Selamet Matbaasında basılmıştır. 279-357 numaralı sayılar 15 günlük sürẻlerle yayımlanmıştır. 280 numaralı sayıda sayfa sayısı 8'e inmiştir. 285 numaralı sayıdan 292 numaralı sayıya kadar Iş Matbaasında ve 293 numaralı sayıdan 296 numaralı sayıya kadar ise Orhaniye Matbaasında basılmıştır.

382 numaralı sayıdan itibaren naşiri İrfan Emin olmuştur. Bu durum 344 numaralı sayıya kadar devam etmiştir. Bu sayıdan 357 numaralı sayıya dek İctihad, Abdullah 
Cevdet ve İrfan Emin tarafından çıkarılmıştır. 328-358 sayılar, İsmail Hakkı Matbaası'nda yayımlanmıştır. 341 numaralı sayıda 12 'ye çıkan sayfa sayısı 343 numaralı sayıda 8'e, 344 numaralı sayıda yeniden 12 'ye, 346 numaralı sayıda tekrar 12'ye çıkmıştır. 354 numaralı sayıda sayfa numaralarında karışıklık mevcuttur.

İctihad Dergisi'nin, yayımlandığı Batıcı yazılardan dolayı, bu düşüncelerden rahatsızlık duyan İslâmcı ve Türkçü yayın organları ile polemik içine girmiştir. Ancak yaydığı Batıcı düşüncelerden rahatsız olanların bazıları İctihad`1 Şeyhülislâmlık, Emniyet Müdürlügüu, Adliye Nezareti, Dahiliye Nezareti, Sadrazamlık gibi kurumlara dinsizlik, halkı galeyana getirme, İslâm dinine, din büyüklerine ve İslâmî kurumlara hakaret gibi gerekçelerle şikayet etmişlerdir. Bu şikayetlerin bazıları yerinde bulunmuş ve İctihad birçok defalar kapatılmıştır. İctihad ise her firsatta, yazarlarının dinsiz olmadığını, dinsizlik propagandası yapmadığını ve İslam'a küfür suçunu işlemediğini dile getirmiştir. Bu durumu, İctihad'da yayımlanan haklı yazılara kalemleriyle karşılık veremeyenlerin oyunu olarak telakki etmiştir. Sik sık İctihad'1 şikayet edenlere, İctihad'la kalemleriyle mücadele etmesini ögütlemiştir. ${ }^{21}$

Buha rağmen İctihad'ın irtica yapmakla ithâm ettikleri, şikayetlerinden vazgeçmemiş ve hatta bazı idarecileri etkilemek suretiyle kendi lehlerine, İctihad aleyhine durumlar oluşturmuşlardır. İstanbul Muhafızlığı, softaların istekleri doğrultusunda İctihad'm tepkisini çeken birçok cezaya imza atmıştır. Bu cezaları eleştirdiği için İctihad'ı da cezalandırılmıştır. ${ }^{22}$

1913 yılında İctihad, irtica ve Hükümeti eleştirmek suçundan beş defa tatil edilmiştir. Bu dönemde Enver Bey'in yönettiği Babıali baskını, Mahmut Şevket Paşa'nın iktidara gelmesi ile İttihadcıların iktidara hâkim olması, Mahmut Şevket Paşa suikastı ile başlayan İttihad ve Terakki diktatörlügünün baskı ortamının tüm basın üzerinde tahammülü güç bir sansür oluşturduğu da unutulmamalıdır.

İctihad Dergisi, 10 Nisan 1330 ila 15 Mart 1926 (100-200 sayıları arası) 2 defa kapatılmış ve yedi defa da çıkışı aksamıştır. 106-109 ve 129-136 sayıları arası "İştihad" adıyla neşredilmiştir. 110. Sayı, "Alem-i Sanayi ve Ticaret Mecmuası" adı ile yayımlanmıștır. 30 Kanun-1 Sani 1330'da, kapatılmış ve tekrar üç yıl on gün sonra 1 Teşrin-i Sani $1918^{\prime}$ de açılmışır. Kapatılmasının sebebi, savaş zamanında askerî hükümetinin kararıyla süresiz tatil edilmesidir. Yeniden yayma "Iștihad" adı başlamıştır. 128. sayıdan 136. sayıya kadar bu isim kullanılmıştır. 132. sayıda yayımlanan "Yara ve Tuz" adlı bir yazı dini tezyif edici bulunmuş ve 138. sayı ile 9 Kanun-1 Sani 1919 'da tekrar kapatılmıştır. Bu kapatmanın süresi, 2 y1l on ay olmuştur. Mahkemede beraat eden İctihad, 30 Teşrin-i Sani 1921 'de 139. sayı ile tekrar yayına başlamıştır.

İctihad, 100 ila 200. sayıları arasında yedi defa gecikmeli yayımlanmıştır. İctihad'ın 117. sayısı 28 gün, 118. sayısı 34 gün, 119. sayısı 14 gün gecikmeli neşredilmiştir. $\mathrm{Bu}$ gecikmelere çeşitli mahkemeler sebep olmuştur. Abdullah Cevdet'in Bahaîlik hakkında bir yazısı yayımlanınca, yazar iki yıl hapse mahkum olmuş, bu ceza uygulanmamakla beraber, derginin 148. sayısı üç ay on gün gecikme ile çıkmıştır. Yayımlanma tarihi 10 Ağustos 1922 olan 149. sayı, Dr. Abdullah Cevdet yargılandığı için 11 Eylül 1922'de yayımlanı̧ıştır. 
İctihad'ın 101-121 sayıları Matbaa-1 Hayriye ve Şürekası'nda, 122-127 sayılar Matbaa-i İctihad'da, 128-135 sayıları Matbaa-1 Osmaniye'de, 136-138 sayıları Matbaa-1 İctihad'da, 139. sayı Orhaniye Matbaası'nda, 140-143 sayıları Hilâl Matbaası'nda, 144152 sayılar Necm-i İstikbal Matbaası'nda, 153-167 sayılar Kader Matbaası'nda, 187-191 sayılar İkdam Matbaası'nda, 194-199 sayılar îkdam Matbaası'nda ve 200. sayı Matbaa-i Amire'de basılmıştır.

İctihad Dergisi'nin 101-129 sayılarında Müdür-i Murahhaslığını İlhami Safa, 132-138 sayılarında Peyami Safa yapmıştır. Müdür-i Mesullük vazifesinin ise, 101-105 sayılarında Fuad, 106-107 sayılarında Ruşen, 108-109. sayılarda Fuad, 110. sayıda Abdullah Cevdet, 111-129. sayılarda Zaven, 130- 135. sayılarda Süleyman Tevfik üstlenmişlerdir. 136-137. sayılarda Müessisi Abdullah Cevdet ibaresi yer almıştır. 139-148. sayılarda Abdullah Cevdet adı basılmıştır. 149-151. sayılarda Müdür-i Mesul olarak Münir Süleyman, 152200 sayılarda ise Abdullah Cevdet adı bulunmaktadır.

İctihad' da bazı yanlışlar da bulunmaktadır. 153. sayıda 3170-3174 arasındaki sahifeler 1370-1374, 200. sayıda 3909-3924 olması gereken sahifeler 3009-3024 basılmıştır. 101106. sayılarda tefrika olarak yayımlanan "Werther" in sahife numarası yoktur. İctihad, 101. sayıdan itibaren 1. sahifeden başlamış, 127. sayının sonuna kadar (478. sahifeye) bu şekilde devam etmiştir. 128. sayının ilk sahifesine 2759 ile başlanmıştır. Halbuki 100. sayı 2270 numaralı sahife ile bitmiştir. Buna 478 sahife ilâve edilince 2748. Numaralı sahife olması gerekirken 128. sayı 2759. ile başlamaktadır. Aradaki 10 sahifenin ne olduğu bilinmemektedir.

187. sayının geç yayımlandığı ve İkdam Matbaası'nda basıldığına dair başında bir açıklama mevcuttur. Ancak üstündeki neşir tarihi, normal neşir tarihi olan 1 Eylül 1925 'tir. 155. sayının son sahifesi 3206 ' dır. 156 . sayı ise 3205 'ten başlatılmıştır. 155 . sayının sonunda numarasız iki sahife bulunmaktadır. Yazılar iki sütun halinde ve 33 satır olarak dizilmiştir.

Derginin ebad1 19x27 cm'dir. Her sayı genellikle 16 sahifedir. Bazen 20, kimi zamanda 24, 30, 8 sahife olarak da çıkmıştır. İki sayı, 18 sahifedir. Derginin dış kapakları ilân ve reklamlara tahsis edilmiştir. Her sayının başında kısa not ve açıklamalar vardır. İctihad'daki fotoğraflar dış kapakta veya şahısla ilgili yazıda yer almaktadır. Ancak bazı fotoğraflar, birkaç sahife veya bir sayı sonra da yayımlanabilmektedir.

İctihad'ın yayımı esnasında Dr. Abdullah Cevdet, kendisi gibi düşünmeyenleri dinsiz addeden; İsrail, İngiliz dostu olarak niteleyenlerin taarruzlarından bunaldığını sık sık ifade etmektedir. Dr. Abdullah Cevdet, kendisine ve dergisine husûmet besleyenlerin mevcut hükümetten yardım beklemelerinin boşuna olduğuna dikkat çekmektedir. Okurlarının çoğu dinci kesimden olan Tevhid-i Efkar ve Sebil-ür-Reşad müşterilerinin "neşelenmesi"ni temin maksadıyla İctihad'ın şeytan taraftarı bir dergi olduğu iddia edilmektedir. Dr. Abdullah Cevdet, İctihad'ın şeytan taraftarı bir dergi değil, Allah taraftarı bir dergi olduğunun altını çizmektedir. Dr. Abdullah Cevdet, inandığı Allah'ın Tevhid-i Efkar ve Sebil-ür Reşad'ın vazettiği intikamcı, zalim, Kahhar bir Allah olmadığını, cenneti yaratan, rahman ve rahim olan bir Allah olduğunu belirtmektedir. Dr. Abdullah Cevdet, inandığ Allah'in muhabbet ve merhamet kaynağı olduğunu, intikamcı olmadığını söylemektedir. Halbuki diğerlerinin, vazettiği Allah, cehennemi yaratan, kahredici ve gazap edici bir ilahtır. Dr. Abdullah 
Cevdet, kendileri gibi düşünmediği için kendisini ve İctihad'ı diri diri yakacak tıynette olan muhasımlarının saçının tek teline zarar gelmesinin kendisi için üzüntülere sebep olacağım ifade etmektedir. Dr. Abdullah Cevdet, Tevhid-i Efkâr Gazetesi Sahibi Velid Ebuzziya’nın İstiklâl Mahkemesi'nde yargılanırken Dr. Rıza Nur'un kendisi için Nevrastenik olduğundan "ceza-î ehliyeti" yoktur raporu verdiğine dikkat çekmektedir.

Dr. Abdullah Cevdet, Tevhid-i Efkâr'm toplumu yanlış yönlendirdiği hususları belirtince, bu gazetenin îctihad'ı kendilerini hükümete jurnal etmekle suçladiğını belirtmektedir. Halkın dinî duygularını istismar eden Tevhid-i Efkâr'm hilafeti ilga, hanedanın ülke dişına çıkış konusunda fikir bile beyan etmediğini söylemektedir. Dr. Abdullah Cevdet, 1925 'te milletvekili olması ihtimali belirince Tevhid-i Efkâr Gazetesi'nin hakkında dinsiz olduğu, İngiliz Muhipleri Cemiyeti kurucularından birisi olduğu, Türkiye'ye Avrupa'dan damızlık celbi ile Türk ırkının ıslah etme çabası içinde bulunduğu iddiaları ile yıpratılmaya çalışıldığını ifade etmektedir. Böylece Tevhid-i Efkâr, îctihad'a isnat ettiği jurnalciliğin en mükemmel şeklini ifa etmektedir. ${ }^{23}$

Tevhid-i Efkâr'ın çabaları sonuç vermiştir. Dr. Abdullah Cevdet'in milletvekilliği engellenmiştir. Özellikle bazı şartlar ile Türkiye'ye yerleşmek istediklerini belirttiği muhacirlerin Türkiye'de iskânını öneren tasarısı, Türkiye'ye Avrupa'dan damızlık getirilmesi şeklinde istismar edilmiştir.

1918 yılı içerisinde 1909 'da Sultan II. Abdülhamid'in tahttan indirilmesinden sonra tahta çıkarılan Sultan V. Mehmed Reşad vefat etmiş ve yerine Sultan VI. Mehmet Vahideddin ${ }^{24}$ geçmiştir. Sultan Reşat iktidarı dönemi boyunca, Ittihadçılara mut'î bir siyaset izlemiştir. Yeni padişah ise, bir İttihadçı düşmanıdır. Hatta İttihadçılar tarafından şehzade iken tutuklanmıştır. ${ }^{25} \mathrm{Bu}$ sebeple yeni padişahın İttihadcılara karşı güçlü bir hoşnutsuzluğu bulunmaktadır. Dr. Abdullah Cevdet de, benzer kaderi paylaşmıştır. İttihad ve Terakki Cemiyeti'nin beş kurucusundan birisidir. İstibdat devrinde yurt dişma kaçmak zorunda kalmıs ve istibdadın her türlü zorluğuna göğüs germiştir. İttihadçılar, iktidara gelince İstanbul'a dönmüş, ancak beklediği itibarı görememiştir. Adeta İttihad ve Terakki Cemiyeti'ndeki rolü yok farz edilmiştir. Bunun üzerine İttihadçılar ile görüş ayrılığına düşmüş ve yaptıkları uygulamalara muhalefet etmiştir. Hatta bu uğurda İslâmcılar ile iş birliği yapmıştır. 1. Dünya savaşı başlayınca İttihadçılar, savaşı bahane edip Ictihad'ı susturmuşlardır. Dr. Abdullah Cevdet, Sultan Reşad'ın vefatı ve İttihadçı düşmanı olarak bilinen Vahideddin' in padişah olması ile îctihad'ı yeniden yayımlamıştır.

Dr. Abdullah Cevdet, yeni padişahtan diğer İttihadçı muhalifleri gibi çok şey beklemektedir. Bu ümitlerini de îctihad'daki bir yazısında dile getirmiştir. ${ }^{26}$

Kılıçzâde Hakkı Bey, İctihad'm 55 numaralı sayısında (1329) "Pek Uyanık Bir Uyku" adlı makalesi ile büyük bir sosyal ıslahat ve medenî çalışma programını Türk Kamuoyuna sunmuştur. Bu programda, millî savunma, maarif, kadın, hanedan, İktisadî konular, din,

23 Abdullah, Cevdet, bkz. 1925d: 3509-3511

24 Vahideddin hakkında geniş bilgi için bkz. Bardakçı 1999: 1-679.

25 Vahideddin'in tutuklanması tık. bkz. Bardakçı 1999: 58.

26 Abdullah, Cevdet, bkz. 1918b, 2763-2764 
kızların eğitimi, hukuk, sosyal hayat konularında öneriler yer almaktadır. Aynı yazarın 56 numaralı İctihad'da (1329) "Neden Mağlup Olduk?" başlıklı makalesi yayımlanmıştır. Bu makalede, askerî konular ele alınmaktadır ve bu sayıda Hakkı Bey, "Kılıçzâde" unvanını almıştır. 57 numaralı İctihad'da (1329), bu iki makalenin devamları yayımlanmıştır. Bu makalelerde, on yıl sonra Türkiye Büyük Millet Meclisi Hükûmeti'nin temel prensibi olacak birçok unsur bulunmaktadır. İctihad, yeni rejime rehberlik ettiği iddiasını taşıyacaktır.

Kılıçzâde Hakkı Bey'in 58 numaralı İctihad'da (1329) yayımlanan "Sahte Softalığa ve Dervişliğe İlân-1 Harb" adlı makalesi ile Dr. Abdullah Cevdet'in "Kastamonu'da Kurûn-u Vusta" başlıklı yazısı sebebi ile, 58 numaralı İctihad, (1329) bir hafta üç defa tab' edilmiştir. Ancak bunun ardında İctihad kapatılmış ve 59 numaralı İctihad (1329), "Cehd" adıyla çıkmıştır. İctihad, Kılıçzâde,Hakkı Bey'in yazılarında yer alan konuların Türkiye Büyük Millet Meclisi Hükümeti tarafindan benimsenmesinden mutluluk duymakta ve İctihad'm Batılılaşma, Laiklik ve diğer konulardaki fikirlerin yeni hükümet tarafından hayata geçirilmesini beklemektedir. ${ }^{27}$

İctihad'in yazar karosuna bakıldığı zaman, 28 yıl boyunca Dr. Abdullah Cevdet'in dışında sürekli yazan bir yazarın bulunmadığı görülmektedir. Kılıçzâde Hakkı ve Celal Nuri gibi, Dr. Abdullah Cevdet'ten sonra en uzun süre yazı yazan yazarları bile ancak bir ya da iki yıl süre ile ve düzensiz olarak yazdıkları anlaşılmaktadır. Bu sebeple İctihad, İslâm, Türk Yurdu, Sebiliiir- Reşad gibi ideolojik nitelik taşıyan dergilerden ayrılmaktadır. Sürekli bir yazar kadrosu yoktur. Hatta çekirdek kadro dahi teşekkül etmemiştir. İşin ilginç yanı, yazarlarının arasında batıcı olmayanlar, İslâmcı veya Türkçü tanınanlar da bulunmaktadır. Yazarlar, bir kaç makale ile İctihad'a katkıda bulunduktan sonra, yazılarını kesmektedirler. Bunda Dr. Abdullah Cevdet' in geçimsizliği ve eli sıkılığının önemli bir rolü bulunmaktadır. Dr. Abdullah Cevdet, meslektaşları ile de iyi iliş̧iler içinde değildir.

Dr. Abdullah Cevdet, basın hayatı ile ilgili bir yazı kaleme almıştır. İstanbul da bir "Türk Matbaacılar Cemiyeti" teşekkül etmiştir (1922). Türk matbaacıları ile gayri Müslim matbaacılar arasında bir mücadele başlamıştır. Türk matbaacılar, Türkiye Büyük Millet Meclisi Hükûmeti'nin kendilerini korumasını istemektedir. Zira mevcut büyük matbaa işleri, Gayri Müslim matbaacılara verilmektedir. Türk Matbaacılar Cemiyeti, Ankara'nın İstanbul'daki temsilcisi Refet Paşa nezdinde bunu engellemeye çalışmış, ancak başarılı olamamışlardır.

Dr. Abdullah Cevdet ise devlet himâyesini istemeyenlerdendir. Bunım sebebini ise, devlet himayesinin gelişmeye engel olmasına bağlamaktadır.

"...Devlet himâyesi, himâye olunanın istinatgahını, hanm ruhundan alıp harice çıkanr ve bu suretle himaye olunana azim bir zaaf getirir. Almanya Devleti, Protestan'dir; orada Protestanlar himâye olunur. Protestanlar resmi mevkî-i iktidara kolay gelebilirler, Katolikler ise, bu himâye ve teshilden mahrum olurlar.

Bu sebeple Almanya İmparatorluğunda sınaî, malî, İktisadî tefevvuk Katoliklerdedir. Fransa Devleti'nin resmî dini, Katolikliktir. Burada Protestanlar, devletten himâye ve 
teshilat görmezler. Fransa' da bu sebeple Protestanlar mütefevviktirler."28

Dr. Abdullah Cevdet, basın hayatının gelişmesi için devlet himâyesinden daha fazla şeylere ihtiyaç olduğunu düşünmektedir. Zira devletin ve özel kişilerin vereceği ticarî işler, bir matbaanın tüm işlerinin ancak yüzde yirmisi- otuzudur. Matbaaları yaşatan kitaplar, gazeteler ve dergilerdir. Bunların ucuz ve kaliteli olması için kağıt, mürekkep, makine ve parçasının bol ve ucuz olması gerekmektedir. Dr. Abdullah Cevdet, bir ayda bir vagon kağıdın

gümrügü seksen liradan dört yüz liraya çıktığını ifade etmektedir. Bu aradaki fark matbaalara, oradan da okuyucuya yansıyacaktır. Pahalı kitap satılmayacak, rafta kalacaktır. Kitabın ağır satılması matbaayı yeni kitap, dergi ve gazete basmaktan alıkoyacaktır. Matbaalar işsiz kalınca, matbaa işçilerini ücretsiz izne çıkaracak, bu işçiler ve aileleri sefalete mahkum edilecektir. Dr. Abdullah Cevdet, bu sebeple Türkiye Büyük Millet Meclisi Hükûmeti'nin ithâl edilen kağıtlardan aldığı gümrük resmini artırmaya son vermesini istemektedir. $\mathrm{Bu}$ tutumu, basma yönelik bir engelleme olarak mütalaa etmektedir.

Dr. Abdullah Cevdet, basın hayatının diğer bir meselesi olarak posta ücretlerine dikkat çekmektedir. Matbaa-1 İctihad, en son "Cihan-1 İslâm'a Dair Bir Nazar-1 Tarihi ve Felsefesi" başlıklı tek formalık bir risâle neşretmiştir. Nüshaların tanesi iki kuruşa mâl olmuştur. Yaklaşık bin abonesine yirmi paralık pul yapıștırmak suretiyle postaya verilmiştir. Postahane noksan pul yapıştırıldığına dair bir tezkere gönderince, Dr. Abdullah Cevdet bizzat postaneye gitmiştir. Burada posta ücretlerine zam geldiği ve her postaya iki kuruşluk pul yapıştırması gerektiği, kendisine tebliğ edilmiştir. Aradaki farktan ötürü Dr. Abdullah Cevdet, sadece seksen adet postalayabilmiştir. Maarife, okuma yazmaya ve eğitime bu kadar önem verildiği bir dönemde, kitap ve dergilerin posta ücretlerini artırmak mantıkî bir uygulama değildir.

Dr. Abdullah Cevdet, İngiltere'de de Posta teşkilâtının zarar ettiğini, buna çözüm olarak posta ücretlerini yarıya indirilmek suretiyle sürümden üç ay içinde iki misli kar edildiğine dikkat çekmektedir.

"Eğer benim risâlem yirmi paralık pulla gönderilebilseydi, şimdiye kadar bin tane postaya verilmiş ve postahane beş yüz kuruş almış olürdu. Şimdi ise ikişer kuruştan seksen tane gönderdim ki cem'an yüz atmış kuruş eder." 29

İctihad, yirmi üçüncü senesinde, kendisini olgunlaşmış bir ağaca benzetmektedir. Her yıl, yeni ve taze çiçek ve meyve vermeye hazırdır. İctihad, aradan geçen yirmi iki sene zarfında neyi savunduysa, haklılığı ortaya çıkmıştır. İctihad, edebî, sanaî, İçtimâ̂, İktisadî, sıhhî bir dergi olarak herkesin ihtiyacına cevap vermektedir. Ayrıca İctihad, felsefe, sosyoloji ve diğer düşünce ile ilgili konulardan bahsetmek suretiyle halkı aydınlatmaya devam etmektedir. İctihad yayınevi her sahada yazılmış eserleri tercüme etmektedir. Bunlar daha ziyâde fikri ilerlemeye dairdir. 
Dr. Abdullah Cevdet, İctihad'm ilk sayısında yayımlanan fikirlerinden yirmi iki yıl boyunca ayrılmadığını ifade etmektedir. Dr. Abdullah Cevdet, İctihad'ın gelişiminde Alişanzâde İsmail Hakkı Bey’in yeni fikirlerinin rolünü yad etmektedir. îctihad, "iyi", "güzel" ve "doğru' yu amaçlamaktadır ${ }^{30}$

İctihad, yirmi üçüncü senesinde kültür alanında gelişmeye ve inkılâplara olan inancı konusundaki kararlılığında devam edeceğini ifade etmektedir. Yeni Türkiye Cumhuriyeti’nde İctihad'm y1llar boyunca ileri sürdüğ̈̈ fikirler birer birer gerçekleşmektedir. İctihad, Cumhuriyetin bu çabalarını elinden gelen desteği vereceğini anlatmaktadır. Bu amaçla İctihad'in fiyatı artırılmış ve sayfa sayısı 24 'e çıkarılmıştır. Ayrıca derginin on beş günden bir yerine haftalık olarak yayımlanmasına gayret edilecektir. Ayrıca İctihad, sütunlarını gençlere açtığını duyurmaktadır. ${ }^{31}$

\section{SONUÇ}

Batıcı düşüncenin hayat tarzı olarak savunulduğu İctihad Dergisi'nin yayın hayatından yola çıkarak, burada yayımlanan makaleleri analiz etmeyi amaçladığımızı ifade etmiştik. Yüzlerce makale, analiz yöntemi ile incelenmiştir. Diğerleri ise, araştırmacılara kolaylık olsun diye dipnotlarda referans olarak verilmiştir. Ayrıca bu analizlerin ışığında 19041932 yılları arasındaki Batıcılık anlayışı, Hamidî, Meşrutî devirler ile Cumhuriyet rejimi dönemindeki gelişmeleriyle beraber ortaya konulmuştur.

Sonuç olarak, XX. yüzyılda Türk toplumu, yüzyıllardır askerîyenilgiler sonucu Osmanlı Devleti'nin dikkatini çeken ve benzemeye çalıştığı Batıya, büyük oranda entegrasyonunu tamamlamıştır. 1904'ten 1932'ye olan süreçte, Batıcılık konusunda yapılan önerilerin, Batılılaşma plân ve programlarının, taktiklerinin çoğunun İctihad Dergisi kaynaklı olduğu tespit edilmiştir. Laik toplum, şapka devrimi, harf inkılâbı, sanayi, ticaret alanındaki yenilikler, giysilerde ve eğitimde inkılâp, kültür inkılâpları, dış politikada kararlılık, çağdaş yaşam v.s. hakkındaki öneriler, ilk defa îctihad'ın sütunlarında yankı bulmuştur. İctihad, yayın hayatı boyunca kararlı Batıcı tutumunu sürdürmüştür.

Ancak Cumhuriyet döneminde, önerdiği fikirlerden ilham alan Cumhuriyet idarecileri arasında Dr. Abdullah Cevdet bulunmamaktadır. Düşüncelerinin gerçekleştiğini gören Dr. Abdullah Cevdet için, düşüncelerinin gerçekleşmesinde etkin rol oynamamak her halde acı olsa gerektir. Fakat

İctihad, yine de Cumhuriyet rejimini desteklemiştir. İnkılâplara sahip çıkmıştır. Zira Sultan II. Abdülhamid'e muhalefet eden, Meşrutiyeti herkesten çok arzulayan ancak Meşrutiyette arzuladığını bulamayan, İttihad ve Terakki'nin kurucuları derginin yazarları olduğu halde, Itttihad ve Terakki iktidarına muhalefet etmiştir. Birinci Dünya Savaşı sonrası Anadolu Hükûmeti'ne karşı İstanbul Hükûmeti'ni destekleyen, ancak Büyük Zafer'den sonra yanlışından dönen İctihad'ın Čumhuriyet döneminde de belirleyici tespitler yaptığını, inkılâpları yönlendirmeye çalıştı̆̆ı müşahede edilmektedir.

1

30 İctihad, bkz. 1927a, 4463-4464

31 İctihad, bkz. 1927b, 4464-4465 


\section{KAYNAKÇA}

ABDULLAH CEVDET. “İctihad.”'İctihad, 1,1 Eylül 1904b: 1-2.

ABDULLAH CEVDET. "26 Teşrin-i Evvel Tarihli 'Son Telgraftan Aynen Abdullah Cevdet Bey'in Teessürü Ziya'nın Ziyal.” İctihad, 171,1 Teşrin-i Sani 1924b: 3457-3458

ABDULLAH CEVDET. "Dil Mesti-Î Mevlana.” îctihad, 86, 26 Kanun-1 Evvel 1329f: 1898-1902.

ABDULLAH CEVDET. "Dilimle İkrar, Kalbimle Tasdik Eylerim.” İctihad, 28 Teşrin-i Sani 1329ad: 1809-1810. ABDULLAH

ABDULLAH CEVDET. “îctihadları İçtihadımıza Muhâlif Olanlar.” İctihad, 60, 4 Nisan 13291: 1306

ABDULLAH CEVDET. “İlm-i Elsine-i Kiyasiye'den Bir Nebze.” îctihad, 43, 15 Mart 1328b: 1041.

ABDULLAH CEVDET. “İstanbul Muhafızlığının Tamimi.” îctihad, 72, 18 Temmuz $1329 \mathrm{v}: 1594$

ABDULLAH CEVDET. "Matbaalar ve Matbuât Hakkında" İctihad, 1581 Teșrin-i Evvel 1923f: 3244-3247.

ABDULLAH CEVDET. "Matbaalar ve Matbuât Hakkında"İctihad, 1581 Teşrin-i Evvel 1923f: 3244-3247.

ABDULLAH CEVDET. "Maziyi Yaşamak Gayreti” İctihad, 175, 1 Mart 1925d: 3509-3511.

ABDULLAH CEVDET. "Yeni Padişahımız." İctihad, 128, 1 Teşrin-i Sani 1918b: 2763-2764.

ALI REŞAD. Türkiye ve Tanzimat, İstanbul: 1328 ALI RIZA SEYFI. "Wodsworth, İniliz Edebiyatına Dair.” İctihad, 71,11 Temmuz 1329a: 1561-1565. Bakışlar, İstanbul: 1959

BARDAKÇI, Murat. Şahbaba,7.bs., İstanbul: Pan Yayıncılık, 1999

BERKES, Niyazi. Türk Düşününde Batı Sorunu, İstanbul: Bilgi Yay. 1975 BERKES, Niyazi. Türkiye 'de Çağdaşlaşma, 2.bs. İstanbul: Doğu Batı Yay. 1978

BERKES, Niyazi. Türk Düşününde Batı Sorunu, İstanbul: Bilgi Yay. 1975 
BERKES, Niyazi. Türkiye 'de Çağdaşlaşma, 2.bs., İstanbul: Doğu Batı Yay. 1978

CELAL NURİ. "Celal Nuri Bey'in Cevaphâmesi Suretidir." İctihad, 56, 28 Şubat 1328a: 1239LANDAU, Jacob M. Tekinalp, Bir Türk Yurtseveri (1883-1961) İstanbul: İletişim Yay, 1994

Düşünce, C.I., İstanbul. İletişim Yay., 2001: 72-87.

KILIÇZÂDE İ. HAKKI. "Kılıçzâde Hakkı Bey ve İki Mektubu." İctihad, 151,1 Şubat 1923e: 3132-3134 KOCA, Ferhat. "Son Dönem Osmanlı Aydınlarının Hilâfet Tartışmaları"” Osmanlı 'dan Cumhuriyet 'e Siyaset ve Değer Tartışmaları, İstanbul: Rağbet Yayınları, 2000: 277-292.

KOÇAK, Cemil. "Yeni Osmanlılar ve Birinci Meşrutiyet." Modern Türkiye'de Siyasi

KURAN, Ahmet Bedevi İnkılâp Tarihimiz ve "Jön Türkler, İstanbul: LEWÎS Bemard. Modern Türkiye'nin Doğuşu Ankara: T.T.K. Yay, 1984 LEWIS Bemard. Ortadoğu (Hiristiyanlığın Doğuşundan Günümüze

M. NACİ. “Tarih-i İstikbâl.” İctihad, 85, 19 Kanun-1 Evvel 1329b: 1876-1878.

MARDIN, Şerif. "Yeni Osmanlı Düşüncesi”" Modern Türkiye'de Siyasi Düşünce, C.I., İstanbul, İletişim Yay., 2001: 42-53. MEHMED ALI TEVFIK. "Elçi Hanımlar." İctihad, 165, 1 May1s 1922: 3349-3350.

ÖZDEN, Barış Alp ve A. Lök. “Ahmed Rıza.” Modern Türkiye «de Siyasi Düşünce, C.I, İstanbul, İletişim Yay., 2001: 120-123.

Tan Matbaası 1945 KURAN, Ahmet Bedevi. İnkılâp

TUNAYA, Tarık Zafer. Hürriyetin İlânı: İkinci Meşrutiyetin Siyasi Hayatına

TUNAYA, Tarık Zafer. İslamcılık Akımı, İstanbul: Simavi Yay., 1991 TURHAN, Mümtaz. Kültür Değişmeleri, 2. bs, İstanbul: Marmara Üniversitesi İlahiyat Fakültesi Yayınları, 1994

TUNAYA, Tarık Zafer. Medeniyetin Bekleme Odasında, İstanbul, Bağlam

TÜRKKAHRAMAN, Mimar. Türkiye 'de Siyasal Sosyalleşme ve Siyasal Sembolizm, İstanbul: Birey Yayıncilik, 2000 1994

ÜLKEN, Hilmi Ziya, Türkiye ‘de Çağdaş Düşünce Tarihi, 4.bs. İstanbul: Ülken Yay, 